\title{
Carrying a Big Carrot: Linking Multilateral Disarmament and Development Assistance
}

David A. Koplow

Georgetown University Law Center, koplow@law.georgetown.edu

Philip G. Schrag

Georgetown University Law Center, schrag@law.georgetown.edu

This paper can be downloaded free of charge from:

https://scholarship.law.georgetown.edu/facpub/1165

91 Colum. L. Rev. 993-1059 (1991)

This open-access article is brought to you by the Georgetown Law Library. Posted with permission of the author. Follow this and additional works at: https://scholarship.law.georgetown.edu/facpub

Part of the Defense and Security Studies Commons, Growth and Development Commons, Military, War, and Peace Commons, and the National Security Law Commons 


\section{COLUMBIA LAW REVIEW}

VOL. 91

JUNE 1991

NO. 5

CARRYING A BIG CARROT: LINKING MULTILATERAL DISARMAMENT AND DEVELOPMENT ASSISTANCE

\section{David A. Koplow and Philip G. Schrag*}

\section{INTRODUCTION}

The nearly simultaneous end of the Cold War and outbreak of armed combat in the Persian Gulf area provide dramatic incentives for the United States, the Soviet Union, and other countries to reexamine the nature of the emerging threats to their national security. As we turn our attention away from a single-minded focus upon the specter of nuclear collision between the superpowers, we are immediately confronted by other long-smoldering multilateral issues that will largely define the planet's security concerns into the twenty-first century. Iraq's chemical attacks on Iran and its invasion of Kuwait are harbingers of a world in which the worst apprehensions of intense armed conflict routinely originate in the developing countries, not along the old Cold War borders of Europe.

Two issues are of predominant concern. The first, already apparent problem of this new international order is the continuing proliferation, particularly in developing countries, of modern weapons such as ballistic and cruise missiles, nerve gas warheads and bombs, and nuclear explosives. The entire world is jeopardized by the spread, and the increased probability of use, of these capabilities because, as the Persian Gulf crises illustrate, local hostilities often threaten to erupt into matters of global concern. The second immediate challenge to international security arises from the burgeoning demand for increased development assistance for the impoverished countries of the third world, where the chronic shortages of capital, technology, and expertise have rendered meaningful progress largely impossible and made sheer economic existence problematic. The crushing burden of poverty threatens to explode with disastrous consequences for both developed and developing societies.

Either of these issues alone would be staggering; together they

* The authors are Professors of Law and Directors of the Center for Applied Legal Studies at the Georgetown University Law Center. They are grateful to the Law Center for grants that helped support the writing of this Article; to Robert Mikulak, who first brought the general problem to their attention; and to Maxime Faille, Douglas Feith, Geoffrey Lamb, Alan Neidle, Alan Platt, Dan Ritchie, Alexander Shakow, and the members of the Georgetown University Law Center's Faculty Research Seminar, for comments on earlier drafts of the manuscript. The authors have published a briefer version of the proposal made in this Article in the May 1991 issue of SAIS Review. See II SAIS Review no.2 (Summer/Fall, 1991). 
present an intricate and exceedingly urgent pair of North-South problems. In addition, a third factor-the structural inadequacy of the world's usual political and legal institutions for dealing with issues of this sort-further confounds traditional efforts to create solutions through ordinary treaties or other international arrangements. Under the usual international agreements, most countries have insufficient incentive to band together for common resolution of their problems, too little assurance that violations can be detected and substantiated in a timely fashion, and virtually no effective recourse when aggrieved by another party's violation of its legal commitments.

This Article proposes, as a new element of the "liberal internationalism"1 that should characterize the post-Cold War world, a simultaneous solution to these three problems. The nations of the world should negotiate a series of multilateral agreements to stop the spread of advanced weaponry, and include in each of them, as an overt incentive for developing states to accept the disarmament and verification obligations, provisions that explicitly require the affluent, developed states to make specified monetary and in-kind transfers to the third world parties. $^{2}$ The new regime should also provide stronger-than-customary treaty procedures for clarifying ambiguities, adjudicating claims, and resolving disputes, and should designate one or more multilateral administrative and enforcement agencies dedicated to furthering the agreements. In short, the wealthy countries, which stand to benefit the most from the establishment of a more stable international military environment, should be willing to pay for it. They should provide aid and commercial grants to the developing states that, in turn, should agree to accept significant, verifiable limitations, particularly on high-technology armaments, as an explicit condition for these important financial advantages. While this package approach will not by itself solve all the security difficulties of the next century, it offers the best hope for gaining control over some of them and for channeling our collective energies into productive and mutually beneficial enterprises.

The argument of the Article is developed in the following six parts. Part I examines the problem of multilateral disarmament, summarizing the progress registered to date and the areas in which more needs to be

1. Richard Gardner has defined liberal internationalism as the "intellectual and political tradition that believes in the necessity of leadership by liberal democracies in the construction of a peaceful world order through multilateral cooperation and effective international organizations." Gardner, The Comeback of Liberal Internationalism, Wash. Q, Summer 1990, at 23, 23.

2. The vocabulary used to refer to the economically disadvantaged states of the world is vague and inconsistent. Terms like "third world," "underdeveloped," "less developed," and "developing" have each gained currency, although there is no generally agreed definition of the terms or listing of the states to be included within the terms. This Article uses the phrases interchangeably. See L. Reynolds, Economic Growth in the Third World: An Introduction 5 (1986); Indep. Comm'n on Int'l Dev. Issues, NorthSouth: A Programme for Survival 31 (1980) [hereinafter A Programme for Survival]. 
done. It also demonstrates that the coming decades, even after the ending of the Cold War, will present stark new threats to United States security and world peace, threats that existing arms control institutions and treaty regimes have been unable to anticipate and preempt. Part II addresses the problems of economic development, drawing on the literature describing the importance of judicious foreign assistance in promoting sound economic growth in marginal economies, and assessing the international community's currently inadequate response to this need. It describes the third world's stake in economic development and presents the case for the advanced societies to do more-out of sheer economic and political self-interest, if nothing else. Part III then suggests that future arms control imperatives will present challenges and dangers that are systematically different from those that the world has confronted-and resolved inadequately-in the past. It marshals the evidence for the propositions that the world's current strategies for dampening international conflict through existing types of treaty regimes are already insufficient, and that the trend is worsening.

Part IV presents our proposal for a tradeoff, with the developed states frankly "buying" the arms control they need, and paying for it with guaranteed levels of development assistance that the poor states need. This Part then outlines seven principles that underlie the proposal as a whole and presents some of the nuts and bolts that could make it operational. While the suggestion may seem radical at first blushlegalized "bribery" or "economic imperialism" in some eyes-we think it offers a realistic, efficient solution to otherwise intractable global threats.

Part V deals with some of the most serious objections that might be raised against our strategy, discussing the "morality" of the tradeoff, its political acceptability, the precedents for it, and possible alternatives to it. Finally, the Conclusion offers some observations about the proposal as one component in an overdue, more subtle, conceptualization of national security.

Our thesis is that international agreements linking multilateral disarmament and economic development, though novel and potentially risky, offer the most promising way out of the international community's emerging security impasse. Our program would give both developed and developing states what they need. It would fashion a flexible, enforceable scheme for dealing with the complex fears and incentives that are otherwise unaddressed or confined to under-the-table bargaining. Explicit trading may not seem palatable at first, but equipping future treaties with both positive incentives and negative sanctions, rather than relying exclusively upon negative sanctions alone, could prove to be far more tolerable than any of the alternatives.

\section{The Need for Multilateral Arms Control}

The relationship between the United States and the Soviet Union 
will remain at the center of each of these countries' security concerns for the foreseeable future. ${ }^{3}$ Although these nations have made significant progress on a host of issues, including bilateral arms control, ${ }^{4}$ trade, ${ }^{5}$ human rights, ${ }^{6}$ and regional matters, ${ }^{7}$ the danger of a nuclear war initiated between the superpowers will linger for as long as such weapons remain in their arsenals. ${ }^{8}$ The recent rapprochement between

3. On the American side, for example, even while the defense budget is being cut somewhat in response to events inside the Soviet Union and Eastern Europe, the Bush Administration has proposed that the spending on strategic nuclear forces (dedicated principally to deterring the U.S.S.R.) should actually increase, and larger cuts should be taken out of general purpose conventional forces. See Graham \& Bunn, Budget Shifts Resources from Conventional to Strategic Forces, Arms Control Today, Feb. 1990, at 29, 29. Secretary of Defense Richard Cheney has stressed the continuing nature of the Soviet threat and cautioned that the American military must still be capable of responding to the U.S.S.R.'s power. See Halverson, As Defense Budget Battles Continue, Cheney Blasts Congress on Soviet Threat, Arms Control Today, Sept. 1989, at 29, 29.

4. Recently, for example, the Soviet Union has admitted that the radar facility it had under construction near the city of Krasnoyarsk was illegal under the Treaty on the Limitation of Anti-Ballistic Missile Systems, May 26, 1972, United States-U.S.S.R., 23 U.S.T. 3435, T.I.A.S. No. 7503 [hereinafter ABM Treaty]. Soviet officials have agreed to dismantle the facility in its entirety, without preconditions-a step that removes a major irritant from U.S.-Soviet arms control negotiations. See Bunn, The ABM Treaty: Toward the 21st Century, Arms Control Today, Apr. 1990, at 13, 13.

5. At the 1990 summit meetings in Washington, D.C., President Bush and President Gorbachev signed treaties to lower trade tariffs between the two states, to grant the Soviet Union "most favored nation status," and to sell quantities of grain to the U.S.S.R. See Farnsworth, Trade Accord Holds Many Prizes, But Obstacles to Passage Remain, N.Y. Times, June 2, 1990, at 7, col. 1; Rosenthal, Bush and Gorbachev Sign Major Accords on Missiles, Chemical Weapons and Trade, N.Y. Times, June 2, 1990, at 1, col. 6.

6. The 1990 Washington summit meetings produced progress, but not complete U.S.-Soviet accord, regarding Jewish emigration from the U.S.S.R. to Israel. Moscow has granted an increased number of exit visas, but concern lingers over the resettlement of new immigrants in Israeli occupied territories. The United States has tied progress in economic and trade issues to Soviet passage of a new law guaranteeing unfettered emigration rights. See Rosenthal, Summit Talks End with Warmth But Fail to Resolve Key Issues, N.Y. Times, June 4, 1990, at Al, col. 6.

7. The United States and Soviet Union have disagreed over some of the fundamental aspects of the political reconfiguration of Eastern Europe, including questions such as the future of a reunified Germany and the political independence of the Baltic states. See Rosenthal, supra note 6, at A1, col. 6. Nevertheless, they, along with the other countries of Europe, have already begun disengaging their conventional military forces on the European continent. See Treaty on Conventional Armed Forces in Europe, Nov. 19, 1990, 30 I.L.M. 1 (1991) [hereinafter CFE Treaty].

8. During the Reykjavik summit meeting on October 11-12, 1986, President Reagan and President Gorbachev raised far-reaching proposals to abolish nuclear weapons entirely-the first time that such visionary notions had been seriously addressed by the superpowers. But those discussions quickly came unraveled, and arms control has continued to concentrate on more modest objectives. See Bertram, US-Soviet Nuclear Arms Control, 1987 Stockholm Int'l Peace Res. Inst. (S1PRI) Y.B., World Armaments and Disarmament 323, 323-27 [hereinafter 1987 SIPRI Y.B.]; Stutzle, Introduction: 1986-A Year of Peace?, 1987 SIPRI Y.B. xxv, xxix-xxxiv. Even under the terms of the contemplated "deep cuts" START agreement, for example, the United States and Soviet Union would each retain thousands of nuclear warheads and systems for delivering 
the first world and the second world has been stunning, ${ }^{9}$ but it augurs a security apparatus in which complex issues will persist, ${ }^{10}$ and the relationship between erstwhile antagonists will now be characterized by a shifting, uncertain mixture of competition and cooperation in economic, military, diplomatic, and other spheres. ${ }^{11}$

Even as the Cold War is losing its grip on our imaginations, ${ }^{12}$ the fears that bedeviled a generation of security experts are taking new forms. ${ }^{13}$ Scenarios describing progressive bipolar escalation to nuclear war $^{14}$ have given way to newer but equally horrific scenarios depicting the United States becoming enmeshed in nuclear conflicts that originate in the Middle East or South Asia. ${ }^{15}$ The planet now presents a

those devices upon targets anywhere in the world. See Gordon, Talks Fail to End Disputes on Long-Range Weapons, N.Y. Times, June 2, 1990, at 4, col. 1; Rosenthal, supra note 5 , at 1 , col. 6 .

Even a limited nuclear war-one involving relatively small numbers of weapons and confined to a few countries-would have catastrophic effects on global climate and ecology, jeopardizing all countries. See Robock, New Models Confirm Nuclear Winter, Bull. Atom. Scientists, Sept. 1989, at 32, 32-35; Turco, Toon, Ackerman, Pollack \& Sagan, Climate and Smoke: An Appraisal of Nuclear Winter, 247 Science 166, 166 (1990).

9. See Final Declaration Issued by NATO Summit Leaders, reprinted in This Alliance Must and Will Adapt, Wash. Post, July 7, 1990, at A18, col. 5 (allied leaders ask Warsaw Pact countries to accept "a joint declaration in which we solemnly state that we are no longer adversaries").

10. The possible political disintegration of the Soviet Union, as constituent republics declare their autonomy, adds a new element of uncertainty to the global calculation. See Dobbs, Ukraine Makes Broad Statement of Sovereignty, Wash. Post, July 17, 1990, at A1, col. 5. The Cold War at least provided a sense of stability and clarity about international affairs, while perestroika may prove to be only a transitory phenomenon, pending the breakup of the U.S.S.R. into several unstable factions, some of which might be less responsible custodians of nuclear weapons than any past Soviet leaders. Cf. Mearsheimer, Why We Will Soon Miss the Cold War, Atlantic, Aug. 1990, at 35, 35 (greater political autonomy for European states may increase probabilities of nuclear weapons proliferation and of European war, as rigidity of bipolar continental balance of terror is relaxed).

11. See J. Baker, A Sound Investment in Freedom's Future, Secretary of State's Testimony Before the Subcomm. on Commerce, Justice, State and Related Agencies of the Senate Appropriations Comm., Apr. 25, 1990, reprinted in U.S. Dep't of State, Current Pol'y No. 1275, at 2 (describing shared interests between United States aud Soviet Union, but also calling for realistic, cautious approach to ongoing perestroika).

12. During the 1990 Washington summit, President Bush observed that "[w]e've moved a long, long way from the depths of the cold war." Rosenthal, supra note 6, at A11, col. 6. A recent public opinion poll indicates that two-thirds of the American public agrees that "the Cold War between East and West is coming to an end" and that by substantial margins, those surveyed consider international terrorism, drug trafficking, and the economic power of Japan each to be greater threats to the United States than is the military power of the Soviet Union. See Washington Post-ABC News Poll, Wash. Post, May 27, 1990, at A24, col. 4.

13. Cf. Klare, An Arms Control Agenda for the Third World, Arms Control Today, Apr. 1990, at 8, 8-12 (arms rivalries among developing countries now pose important threats to peace worldwide).

14. See Kahn, On Escalation: Metaphors and Scenarios (1965).

15. See Jones \& Müller, Preventing a Nuclear Sarajevo: Proliferation in the Middle 
more complex array of political actors, with diverse centers of power and danger, and with many more states clamoring for attention, autonomy, and influence. The United States and the Soviet Union can no longer call as many shots as they once could; as a result, their security will increasingly depend upon the voluntary cooperation and self-restraint of others. ${ }^{16}$

The world has long acknowledged the growing importance of a multilateral approach ${ }^{17}$ to arms control, ${ }^{18}$ and several significant multilateral arms control agreements reflect the value of a global solution to the problems. ${ }^{19}$ The 1963 Limited Test Ban Treaty (LTBT), ${ }^{20}$ the

East and South Asia, Arms Control Today, Jan./Feb. 1989, at 15, 15-16; Spector, Nonproliferation: After the Bomb Has Spread, Arms Control Today, Dec. 1988, at 8, 8-10.

16. For example, in the ongoing negotiations toward an "Open Skies" agreement (a treaty that would permit reciprocal aerial overflight and reconnaissance over the territories of the NATO and Warsaw Pact states), the former Soviet "satellite" countries of Eastern Europe have distanced themselves from the negotiating positions advocated by the U.S.S.R., staking out independent attitudes in a fashion that would not have been possible a few years ago. See Howard, Soviets Gain Little Support for Proposal, Toronto Globe \& Mail, Feb. 5, 1990, at A4, col. 6; Lewis, Soviet Position at 'Open Skies' Talks Puzzles West, N.Y. Times, Feb. 25, 1990, § 1, at 11, col. 1.

17. The principal multilateral fora for addressing arms control issues are the United Nations (where discussions have centered in the General Assembly, the First Committee, the three special sessions on disarmament, the Disarmament Commission, and several ad hoc committees); the Conference on Disarmament (a 40-member negotiating body based in Geneva, affiliated with the U.N. but autonomous from it, which has served as the principal mechanism for the multilateral elaboration of treaty texts); the Department for Disarmament Affairs of the U.N. Secretariat (the focus of the SecretaryGeneral's activities in the field); and the United Nations Institute for Disarmament Research (an autonomous research institution). See [1988] 13 U.N. Disarmament Y.B. 8-13, U.N. Salès No. E.89.1X.5 (1988); Graham, A Brief Guide to the United Nations Disarmament Machinery, in Disarmament and World Development 227 (M. Graham, R. Jolly \& C. Smith eds., 2d ed. 1986).

18. The terms "arms control" and "disarmament" refer to measures designed a) to make the outbreak of war less likely, b) to decrease the damage inflicted, if war does occur, and c) to reduce the economic burdens of peacetime preparations for war. See Luck, Placing Conventional Arms on the Multilateral Agenda, in Arms Control: The Multilateral Alternative 177, 182 (E. Luck ed. 1983). Specialists sometimes differentiate between the two terms by reserving "disarmament" to refer to programs that would abolish, rather than simply control or limit, specified categories of weaponry.

19. See Jaipal, Disarmament Negotiations: Multilateral and Bilateral, in U.N. Inst. for Disarmament Research, Interrelationship of Bilateral and Multilateral Disarmament Negotiations: Proceedings of the Baku Conference, June 2-4, 1987, at 7, 7-15, U.N. Sales No. GV.E/F.88.0.1 (1988) [hereinafter Proceedings of the Baku Conference]; U.S. Arms Control \& Disarmament Agency, Arms Control and Disarmament Agreements: Texts and Histories of the Negotiations 3-9 (1990) [hereinafter Texts and Histories of Negotiations]; Neidle, The Rise and Fall of Multilateral Arms Control: Choices for the United States, in Arms Control: The Multilateral Alternative, supra note 18, at 7, 8-17.

20. Treaty Banning Nuclear Weapon Tests in the Atmosphere, in Outer Space and Under Water, opened for signature Aug. 5, 1963, I4 U.S.T. 1313, T.I.A.S. No. 5433, 480 U.N.T.S. 43 [hereinafter LTBT]. The LTBT prohibits the testing of nuclear explosive devices anywhere other than underground, where the deadly radioactivity will not leak into the biosphere. It currently has 116 parties. See Annexe A, Major Multilateral 
1968 Non-Proliferation Treaty (NPT), ${ }^{21}$ and the 1972 Biological Weapons Convention (BWC), ${ }^{22}$ among others ${ }^{23}$ have demonstrated that with respect to many military technologies, an effective disarmament measure will require the participation of nearly all of the states of the world.

Notwithstanding the accomplishments of these treaties, however, the world remains a very dangerous place, with many of today's worst security nightmares springing not from superpower confrontations, but from the proliferation, or threatened proliferation, of uncontrolled sophisticated weapons and delivery systems to additional states. ${ }^{24}$ Those

Arms Control Agreements, 1988 Stockholm Int'l Peace Res. Inst. (SIPRI) Y.B., World Armaments and Disarmament 549, 552 [hereinafter 1988 SIPRI Y.B.].

21. Treaty on the Non-Proliferation of Nuclear Weapons, opened for signature July 1, 1968, 21 U.S.T. 483, T.I.A.S. No. 6839, 729 U.N.T.S. 161 [hereinafter NPT]. The NPT obligates those of its parties that do not currently possess nuclear weapons to refrain from acquiring or developing them, and it also obligates the states that do already possess those weapons not to aid others in obtaining them, as well as to share the benefits of nuclear technology and to curtail the nuclear arms race. The NPT currently has 140 parties. See Goldblat, Nuclear Non-Proliferation: A Balance Sheet of Conflicting Trends, 20 Bull. Peace Proposals 369 (1989).

22. Convention on the Prohibition of the Development, Production and Stockpiling of Bacteriological (Biological) and Toxin Weapons and on Their Destruction, opened for signature Apr. 10, 1972, 26 U.S.T. 583, T.I.A.S. No. 8062, 1015 U.N.T.S. 163 [hereinafter BWC]. The BWC prohibits the development, production, stockpiling, acquisition, or retention of biological agents or weapons, other than a small quantity for defensive research. It currently has 110 parties. See Annexe A, 1988 SIPRI Y.B., supra note 20 , at 553 .

23. Other noteworthy multilateral arms control agreements include the Environmental Modification Convention of 1977 (Convention on the Prohibition of Military or Any Other Hostile Use of Environmental Modification Techniques), May 18, 1977, 31 U.S.T. 333, T.I.A.S. No. 9614, 1108 U.N.T.S. 152 [hereinafter Environmental Modification Convention] (banning the use of techniques of environmental modification in war); the Seabeds Arms Control Agreement of 1971 (Treaty on the Prohibition of the Emplacement of Nuclear Weapons and Other Weapons of Mass Destruction on the Seabed and the Ocean Floor and in the Subsoil-Thereof), Feb. 11, 1971, 23 U.S.T. 701, T.I.A.S. No. 7337, 10 I.L.M. 146 [hereinafter Seabeds Arms Control Treaty] (prohibiting deployment of nuclear weapons under the oceans); the Treaty of Tlatelolco of 1967 (Treaty for the Prohibition of Nuclear Weapons in Latin America), Feb. 14, 1967, 634 U.N.T.S. 281 [hereinafter Treaty of Tlatelolco] (declaring entirety of Latin America to be nuclearweapons-free zone); the Outer Space Treaty of 1967 (Treaty on Principles Governing the Activities of States in the Exploration and Use of Outer Space, Including the Moon and Other Celestial Bodies), Jan. 27, 1967, 18 U.S.T. 2410, T.I.A.S. No. 6347, 610 U.N.T.S. 205 [hereinafter Outer Space Treaty] (restricting military activities in outer space and on celestial bodies); the Antarctic Treaty of 1959, Dec. 1, 1959, 12 U.S.T. 794, T.I.A.S. No. 4780, 402 U.N.T.S. 71 [hereinafter Antarctic Treaty] (declaring the continent reserved for peaceful purposes); and the Geneva Protocol of 1925 (Protocol for the Prohibition of the Use in War of Asphyxiating, Poisonous or Other Gases, and of Bacteriological Methods of Warfare), June 17, 1925, 26 U.S.T. 571, T.I.A.S. No. 8061, 94 L.N.T.S. 65 [hereinafter Geneva Protocol] (banning the first use of chemical weapons in war). See Texts and Histories of Negotiations, supra note 19, passim.

24. "Low intensity warfare," defined as limited hostilities confined to a particular zone and usually designed to combat revolutionary guerrillas and regimes, has become increasingly important to United States military planning. See Barnet, U.S. Interven- 
who may have imagined that "peace is at hand" merely because of the superpower rapprochement may have been rudely surprised to discover the panoply of future military threats awaiting the economically developed states from a host of newly armed potential adversaries.

First, regarding chemical weapons (CW), the leading countries are coming to realize that they, too, are vulnerable to insidious threats: upwards of twenty states are widely considered to possess lethal chemical arms, to be on the verge of developing them, or to have the capability to produce them indigenously on short notice. ${ }^{25}$ Renegades such as Libya and North Korea are increasingly active in the CW arena, ${ }^{26}$ and lraq overtly violated a long-standing international taboo by employing chemical ordnance widely, and with devastating effect, in the war with lran. ${ }^{27}$ More recently, lraq was reported to have loaded chemical weapons onto aircraft for possible use against American forces in Saudi Arabia. ${ }^{28}$

Second, the potential for the imminent dispersal of nuclear weaponry has similarly escalated: Leonard Spector has calculated that while only five states are now acknowledged to possess nuclear arsenals, as

tion: Low-Intensity Thinking, Bull. Atom. Scientists, May 1990, at 34, 34-37. At the same time, American exports of arms-including new high-technology weaponry-to the third world have escalated, see Husbands, A Buyer's Market for Arms, Bull. Atom. Scientists, May 1990, at 14, 14-16, and the indigenous weapons industries in many smaller states have expanded, see Ross, Do-lt-Yourself Weaponry, Bull. Atom. Scientists, May 1990, at 20, 20-22. Overall, the number of heavily armed developing states has increased dramatically in recent years. See Klare, Wars in the 1990s: Growing Firepower in the Third World, Bull. Atom. Scientists, May 1990, at 9, 9-10; Walker, HighTech Killing Power, Bull. Atom. Scientists, May 1990, at 23, 23-26.

25. See Summary of U.S.-Soviet Agreement on Chemical Arms, N.Y. Times, June 2, 1990 , at 8, col. 2. Estimates about the rate of the spread of chemical weapons have varied widely, with some experts suggesting that as few as nine states now possess chemical arms, and others, including the Director of the Central Intelligence Agency, putting the tally as high as $\mathbf{2 0}$ or more. See Global Spread of Chemical and Biological Weapons: Hearings Before the Senate Comm. on Governmental Affairs and 1ts Permanent Subcomm. on Investigations, 101 st Cong., 1st Sess. 10 (1989) (statement of CIA Director William H. Webster); Chemical Arms Control After the Paris Conference, Arms Control Today, Jan./Feb. 1989, at 3, 4 (comments of Elisa Harris from transcript of press briefing); Ember, Worldwide Spread of Chemical Arms Receiving lncreased Attention, Chemical \& Engineering News, Apr. 14, 1986, at 8, 8-16; Lundin, Robinson \& Trapp, Chemical and Biological Warfare: Developments in 1987, 1988 S1PR1 Y.B., supra note 20, at 101, 101-02.

26. Ember notes that only four states (United States, Soviet Union, France, and Iraq) have acknowledged possession of chemical weapons, but eleven more (Egypt, Syria, Libya, Israel, Ethiopia, Burma, Thailand, China, Taiwan, North Korea, and Vietnam) have also been reliably reported to have some degree of chemical warfare capability. See Ember, supra note 25, at 8-16.

27. See id.; Segal, The Iran-Iraq War: A Military Analysis, 66 Foreign Aff. 946, 955-56 (1988); Smith, Relying on Chemical Arms, Wash. Post, Aug. 10, 1990, at A25, col. 1 .

28. See Gordon, Bush's Aims: Deter Attack, Send a Signal, N.Y. Times, Aug. 8, 1990, at A1, col. 5, A9, col. 5 . 
many as ten others are on the threshold or pointed in the same hazardous direction. ${ }^{29}$ Regional arms races in South Asia, ${ }^{30}$ the Middle East, ${ }^{31}$ Africa, ${ }^{32}$ and Latin America ${ }^{33}$ threaten to tilt still more states toward pursuit of a nuclear weapons capability, with additional countries poised to join the exclusive "nuclear club," or being secret members already. ${ }^{34}$ In 1990, during a period of tension between India and Pakistan over Kashmir, United States and Soviet intelligence agencies reported that both of those Asian nations appeared to be preparing to use nuclear weapons if hostilities broke out. ${ }^{35}$

Third, as Janne Nolan and others have pointed out, the capability for delivering these awesome weapons to remote targets has also spread. During the 1980 s, several new states tested or deployed for the first time missiles capable of projecting power at regional or even intercontinental ranges. ${ }^{36}$ Iraq's successful use of missiles to cause terror in Iranian cities "has had an impact beyond Iran and Iraq," according to CIA Director William Webster: "The demand for ballistic missiles has increased among Third World governments. . . B By the year 2000 at least 15 developing countries will be producing their own ballistic mis-

29. See L. Spector, The Undeclared Bomb 3, 69, 161, 231-32 (1988); see also Goldblat, supra note 21, at 369-72 (discussing nuclear proliferation threat from Libya, Iran, Iraq, North Korea, Taiwan, India, Pakistan, Argentina, Brazil, Israel, and South Africa); Jones \& Müller, supra note 15, at 15-18 (surveying dangers of nuclear weapons spread in volatile areas of the world).

30. See L. Spector, supra note 29, at 69-156. Nuclear competition between India and Pakistan has intensified, and both states maintain extensive nuclear programs; neither state probably has a fully assembled nuclear explosive, but both have marshalled all materials and technology necessary to fabricate them on short notice. See id. at 69-70.

31. See id. at 161-227 (Israel now probably possesses at least 50-60 nuclear weapons, and Libya, Iraq, Iran, and Syria have all taken steps toward acquisition of atomic arsenals).

32. See id. at 283-305 (South Africa has probably compiled an arsenal of 10-20 atomic weapons, and Nigeria has expressed an interest in obtaining nuclear arms).

33. See id. at 231-79 (both Argentina and Brazil have continued substantial nuclear programs outside of any system of international monitoring or control; both have pursued projects that could lead toward weapons capability).

34. Cf. Gardner, supra note I, at 31 ("By the year 2000, there will be 40,000 50,000 kilograms of separated plutonium in international commerce as a result of peaceful nuclear activities, a target for theft by terrorists and radical governments."); Milhollin, Attention, Nuke-Mart Shoppers!, Wash. Post, July 22, 1990, at C2, col. I (recent relaxations of Western export controls will make it easier for third world states to acquire nuclear weapons capabilities).

35. See Big 2 Said to Fear Subcontinent War, Wash. Times, May 28, 1990, at A2, col. 3; see also Reingold, India, Pakistan Political Changes May Spur Proliferation, Arms Control Today, Dec. 1989/Jan. 1990, at 26, 26 (internal political pressures inside India and Pakistan may now drive both states to pursue nuclear weapons).

36. See Jones \& Müller, supra note 15, at 17-18; Morrison, Third World Missileers: New Threat?, 22 Nat'l J. 969, 969 (1990); Nolan, Ballistic Missiles in the Third World: The Limits of Nonproliferation, Arms Control Today, Nov. 1989, at 9, 9-10; Schrag, A New Genie Emerging, Christian Sci. Monitor, Apr. 25, 1988, at 14, col. 1. 
siles."37 A state with ballistic missiles could inflict a devastating blow upon its neighbors or others, within minutes of a decision to launch, ${ }^{38}$ and even most militarily developed states have deployed no effective national defenses against them. ${ }^{39}$ The future reality, according to American intelligence estimates, is one in which "ballistic missiles loaded with nuclear or chemical or biological warheads are a major factor of the conflicts in each region of the world."40

Fourth, and perhaps most surprising, many developing states will be capable, within a decade, of including another generation of advanced "conventional" weaponry in their arsenals. 41 Even poor countries will be able to increase radically the destructive power of their armed forces by deploying inexpensive new cruise missiles made of lightweight composite materials. Guided by commercial navigation satellites (rather than by expensive on-board computer maps and mapping sensors), ${ }^{42}$ these devices will be capable of near-perfect accuracy, and they can be equipped with fuel-air explosive warheads of shocking

37. Nuclear and Missile Proliferation: Hearing Before the Senate Comm. on Governmental Affairs, 101st Congress, Ist Sess. 11-12 (1989) [hereinafter Nuclear and Missile Proliferation] (testimony of CIA director William Webster); see also Gardner, supra note 1, at 31 ("There are 9 countries that have both missiles and chemical weapons, and that number could be as high as 15 or 20 by the year 2000.").

38. See Nolan \& Wheelon, Third World Ballistic Missiles, 263 Sci. Am. 34, 39 (1990). An intercontinental ballistic missile (ICBM) takes about 30 minutes to travel the 3000 miles or more from its launch point to its target. See D. Barash, The Arms Race and Nuclear War 23 (1987). Shorter range ballistic missiles, such as those capable of reaching 500-2000 miles, have flight times on the order of 10-15 minutes. Cruise missiles are much slower, flying only approximately as fast as modern airplanes.

39. Regarding intercontinental-range ballistic missiles, both the United States and the Soviet Union have investigated various possible programs of defense against missile attack, and both have from time to time invested heavily in deployment of antiballistic missile interceptors, as well as in programs of anti-air defense, civil defense, and the like. At the present time, however, both superpowers, as well as every other state, are essentially vulnerable to modern methods of ICBM attack. The United States and Soviet Union have therefore relied upon mutual deterrence, rather than active defenses, to render aggression improbable. But there is reason to doubt the credibility of the extension of these deterrence principles to all the newly emerging military forces around the world. See D. Barash, supra note 38, at 110-65; see also Diehl, Israel Tests Defensive Missile, Wash. Post, Aug. 10, 1990, at A25, col. 4 (lsrael is experimenting with antimissile system designed to counter threat of incoming intermediate-range ballistic missiles).

Regarding intermediate-range ballistic missiles, the successes achieved by the United States' Patriot defense system in the Gulf War have suggested that interception (at least of relatively unsophisticated missiles) can be reliably achieved. See Farrell, The Patriot's Success Clouds Arms Debate, Boston Globe, Mar. 24, 1991, at A1, col. 5.

40. Nuclear and Missile Proliferation, supra note 37, at 14 (testimony of ClA director William Webster).

41. See R. Cohen \& P. Wilson, Superpowers in Economic Decline: U.S. Strategy for the Transcentury Era 183 (1990).

42. See Nuclear and Missile Proliferation, supra note 37, at 28-29 (testimony of CIA director William Webster). 
power. ${ }^{43}$ Like nuclear weapons, two or three fuel-air warheads will be able to obliterate a medium-size city, ${ }^{44}$ and there have already been indications that both Iraq and the United States have brandished these new weapons in the Gulf War. ${ }^{45}$

These threats to industrialized societies and to their less industrialized allies, suppliers, and trading partners will surely intensify in the coming years, and additional types of advanced weaponry that have to date been closely restricted may yet leak into the wider market. ${ }^{46}$ Indeed, while it used to be quite rare for developed states to release their highly sophisticated arms to any developing states, those inhibitions have eroded. ${ }^{47}$ A pronounced upsurge in the military power of the de-

43. A fuel-air device "releases an aerosol cloud of explosive gas and then ignites it, creating an explosion nearly as powerful as a small atomic bomb." Stewart, Ballistic Missiles Reshape Power in Third World, San Francisco Chron., Mar. 7, 1990, at 1, col. 3. These devices were first used by the Soviet Union with devastating effect on Afghan rebel troop concentrations, and similar weapons have been included in the arsenal of the United States Air Force. See Sexton, New Soviet Bomb in Afghan War, Newsday, June 13, 1988, at 13, col. 1 .

44. "[U]nprotected humans have virtually no chance of survival" against fuel-air explosives, "seen by some experts as the most powerful conventional weapon of the [1990s]." Austin, Swedish Group Demands Protection Against Inhumane Weapons, Reuters Dispatch, Jan. 5, 1990 (LEXIS, Nexis Library, LBYRPT file). The superpowers are already designing an even more powerful second generation of these devices. See Kaylor, After INF, the Next New Arms Race, U.S. News \& World Rep. May 9, I988, at 26.

45. See Apple, Iraq: Hidden Cards?, N.Y. Times, Jan. 24, 1991, at A12, col. 2; Barry, The Nuclear Option: Thinking the Unthinkable, Newsweek, Jan. 14, 1991, at 16, I7; Cody, Baghdad: Offer Has "No Effect" on Pace of War, Wash. Post, Feb. 16, 1991, at Al, col. 1 .

46. For example, the United States and the Soviet Union have to date dominated the military uses of outer space, and the superpowers are the only states that have invested heavily in programs designed to place weapons into orbit or to shoot down or disrupt the operation of another country's satellites. See Jasani, Military Use of Outer Space, 1988 SIPRI Y.B., supra note 20 , at 75, 81-89. There can be no assurance, however, that this exceptionally destabilizing weapons technology will indefinitely remain out of the reach of other nations. See Dougherty, Prevention of an Arms Race in Outer Space: A Perspective from the United States of America, in Proceedings of the Baku Conference, supra note 19, at 91, 91-98; Rodionov, Prevention of an Arms Race in Outer Space: Bilateral and Multilateral Perspectives, in Proceedings of the Baku Conference, supra note 19, at 108,110-12. Indeed, many nations may soon be drawn into a race to perfect antisatellite weapons, as part of the pursuit of defenses against satelliteguided cruise missiles, see supra text accompanying note 42 .

Similarly, the United States and its allies have a substantial advantage over the Soviet Union--and even more of an advantage over the developing countries-in the technology necessary to produce the next generation of "smart" conventional weapons, and a variety of programs is underway to develop advanced radars, artillery shells, and other arms. See Canby, Conventional Weapon Technologies, 1987 SIPRI Y.B., supra note 8, at 85, 86-93. Again, however, the possibility remains that this technology will, over time, spread to other states. See Mohan \& Subrahmanyam, High-Technology Weapons in the Developing World, in New Technologies for Security \& Arms Control: Threats \& Promise 229, 232-33 (E. Arnett ed. 1989).

47. Beginning in the mid-1970s, the leading military states became increasingly 
veloping states is underway, ushering in an era in which even the traditionally wealthy and powerful countries find themselves jeopardized as never before. ${ }^{48}$

In anticipation of these challenges, arms control negotiators are currently grappling - with different levels of success-with issues as diverse as nuclear weapons testing, ${ }^{49}$ radiological weapons, ${ }^{50}$ conventional forces, ${ }^{51}$ and nuclear free zones, ${ }^{52}$ while many other arms control problems are still lurking in the wings. ${ }^{53}$ Moreover, those same diplomats are now scrambling to try to prevent the modest restrictions of an earlier generation of multilateral arms control accords-notably those

willing to export even their more advanced weapons. See Indep. Comm'n on Disarmament \& Sec. Issues, Common Security: A Blueprint for Survival 27-30 (1982) [hereinafter Palme Commission Report].

48. See Hoffman, U.S., Soviets to Press Arms Talks, Wash. Post, Sept. 27, 1990, at A31, col. 5 .

49. See Donovan, Unlimited Test Ban Treaty?, Arms Control Today, Apr. 1990, at 30, 30; [1988] 13 U.N. Disarmament Y.B. 201-22, U.N. Sales No. E.89.IX.5 (1988).

50. See [1988] 13 U.N. Disarmament Y.B. 306-20, U.N. Sales No. E.89.1X.5 (1988).

51. Two new sets of multilateral negotiations are addressing questions related to conventional (i.e., nonnuclear) military weapons and personnel in Europe. The first Conventional Forces in Europe (CFE) Treaty was signed in November 1990; it begins to reduce the levels of key military equipment on the continent. Under article XV11I, the parties are obligated to continue negotiations, with the goal of agreeing to further force reductions by 1992 . See CFE Treaty, supra note 7, art. XV111, 30 1.L.M. at 22. The Conference on Confidence- and Security-Building Measures and Disarmament in Europe (known as CDE) resumed deliberations in Marcb 1989, and focused on preparing a set of agreements to increase the "transparency" of each state's military apparatus via advance notifications of military maneuvers and invitations to foreign observers, on the theory that those measures-even without any direct reduction in the size of the armies-could reduce fears about a surprise attack, and thus minimize the need to assume the worst about ambignous behaviors. See Borawski, From Stockholm to Vienna: Confidence- and Security-Building Measures in Europe, Arms Control Today, May 1989 , at 11,15 . These negotiations are expected to be demanding and difficult, with a great many tricky and unprecedented issues awaiting resolution. See Hirschfeld, The Toughest Verification Challenge: Conventional Forces in Europe, Arms Control Today, Mar. 1989, at 16, 16. In addition, negotiations regarding conventional forces may arise in other geographic contexts. See Segal, Informal Arms Control: The Asian Road to Conventional Reductions, Arms Control Today, May 1989, at 11, 16.

52. See [1988] 13 U.N. Disarmament Y.B. 234-53, U.N. Sales No. E.89.IX.5 (1988); Hoffman, Shevardnadze Urges Nuclear-Free Zone in Middle East, Wash. Post, Dec. 12, 1990, at A29, col. 1.

53. See, e.g., [1988] 13 U.N. Disarmament Y.B. 344-53, U.N. Sales No. E.89.IX.5 (1988) (recounting efforts to promote multilateral agreement on reciprocal reduction of military budgets); U.N. Dep't for Disarmament Affairs, Reduction of Military Budgets: Refinement of International Reporting and Comparison of Military Expenditures, Report of the Secretary-General, Study Series 10, at 37-38, U.N. Doc. A/S-12/7 (1983) (studying procedures for reporting and cutting military spending); Fieldhouse, The Case for Naval Arms Control, Arms Control Today, Feb. 1990, at 9, 14-15 (argning that United States should now begin to include limiting naval forces and activities in multilateral arms control processes). See generally Goldblat, Multilateral Arms Control Efforts, 1988 SIPRI Y.B., supra note 20, at 347, 357- 58, 364-65 (summarizing progress in various ongoing multilateral negotiating efforts). 
of the NPT ${ }^{54}$ and the BWC $^{55}$-from unraveling under the pressure of unanswered questions about verification and compliance.

In light of these diverse pressures, no state-no matter how wealthy or sophisticated its economy-can reasonably feel very confident in its security or in the prospects for its future safety, and the developed states are particularly exposed. ${ }^{56}$ This century has witnessed an escalating pattern of international and internal violence, as wars have become more common, more protracted, and more deadly, in all sectors of the globe, jeopardizing developing and developed societies alike. ${ }^{57}$

54. Under the NPT, the parties hold a review conference every five years to assess the operation of the treaty; after 25 years, "a conference shall be convened to decide whether the Treaty shall continue in force indefinitely, or shall be extended for an additional fixed period or periods." NPT, supra note 21 , art. VIII, $\S 3$ \& art. X, § 2, 21 U.S.T. at 492-94, T.I.A.S. No. 6839, at 10-12, 729 U.N.T.S. at 174-75. The 25-year evaluation is scheduled for 1995, and although the NPT has become the cornerstone of the international effort to stem the further spread of nuclear weapons, several states have hinted that they may not support a long-term extension of the treaty. Many developing states consider that the superpowers and other developed states have not fully complied with their NPT obligations to arrest their own nuclear arms race and to share the benefits of civilian nuclear power, see infra notes 164-172 and accompanying text. Recent review conferences have therefore become quite contentious, and the 1995 conference may entail substantial international bargaining. See Dunn, Nuclear Proliferation Watch: Some Thoughts on Future Challenges, in New Technologies for Security \& Arms Control: Threats \& Promise, supra note 46, at 91, 96, 100-01; Mayorsky, The Evolving International Consensus on Nuclear Non-Proliferation, in New Technologies for Security \& Arms Control: Threats \& Promise, supra note 46, at 85, 89, 91-92; Graham, The Duration of the Nuclear Non-Proliferation Treaty: Sudden Death or New Lease on Life?, 29 Va. J. Int'l L. 661, 661-66 (1989).

55. The BWC has been ensnarled in a controversy regarding American allegations about an outbreak of anthrax near the Soviet city of Sverdlovsk, reportedly the site of a secret BW facility that suffered a serious accident in 1980. The inability to resolve these concerns satisfactorily has led to proposals to amend the treaty substantially to strengthen its verification provisions. In addition, new biotechnologies related to recombinant DNA have surfaced, challenging the coverage of the existing treaty language, and leading to other proposals for renegotiations to enhance the BWC's scope. See Goldblat, The Review of the Biological Weapons Convention, 1987 SIPRI Y.B., supra note 8, at 409, 410-11; Review Conference Held on Biological and Toxin Weapons Convention, 86 Dep't St. Bull. No. 1247, Dec. 1986, at 40, 42-43.

56. See Chidzero, Disarmament and Development: The Implications for Africa, Disarmament, Spring 1986, at 8, 14:

The world cannot be secure when the rich and prosperous constitute an island in a sea of poverty. They may well be armed to the teeth, girded with all the paraphernalia of sophisticated weaponry, nuclear and conventional, yet it must be increasingly clear that these can only be used effectively at the risk of selfdestruction, instantaneous retaliation and, in the process, destruction of the environment.

See also Holm, World Disarmament: A Strategy for Development?, Disarmament, Spring 1986, at 26, 29 ("All states live in an insecure world and share a common vulnerability.").

57. One authoritative source has identified 36 major ongoing armed conflicts in the world, compared with only three in 1945. See Wilson \& Wallensteen, Major Armed 
A paralyzing variety of scenarios will confront future military planners in the United States and elsewhere. First, as noted, there is the heightened specter of direct attack: long-range aircraft and missiles now put all countries directly within reach of antagonistic forces, and geographic separation-even the buffer of wide oceans- provides only limited protection. ${ }^{58}$

Second, even if they are not attacked directly, the developed countries will still be placed at risk whenever traditional allies or regional affiliates come under fire. For the United States, the dollar costs and numbers of American casualties resulting from being drawn into battle in order to assist a friendly state in resisting aggression could be much higher than in the past as a result of more sophisticated weaponry being used against U.S. forces. ${ }^{59}$

Third, the developed states inevitably will suffer when advanced types of arms cause remote regional conflicts to intensify, as commerce is disrupted and innocent bystanders are drawn in. ${ }^{60}$ The collateral damage from future fighting could be considerable, especially when the sides begin to target each other's industrial production and economic bases.

Moreover, as Elisa Harris has warned, when advanced weapons proliferate still further, the chances increase that terrorist organizations will acquire them, exposing all states to new types of imponderable threats. ${ }^{61}$ The world already has experienced its relative powerlessness in the face of determined subnational groups, especially state-spon-

Conflicts in 1987, 1988 SIPRI Y.B., supra note 20, at 285, 285-98. Several wars have shown a trend toward increasing levels of violence, destruction, and fatalities. See $R$. Sivard, World Military and Social Expenditures 1989, at 22, 23 (1989).

58. See L. Spector, supra note 29, at 27-59; Int'l Inst. for Strategic Studies, The Military Balance 1987-1988, at 92-200 (1987).

59. See Nolan \& Wheelon, supra note 38 , at 34 (noting that Argentina used Frenchsupplied Exocet missile to sink British cruiser during 1982 Falklands war, and that Iraq nearly sank United States destroyer with same system during Iran-Iraq War in 1987).

60. For example, the United States was drawn into the Iran-Iraq war by the need to sustain the flow of oil through the Persian Gulf. Eleven Kuwaiti tankers were reflagged in 1987 as United States vessels, coming under the protection of the American Navy and inserting United States forces into the conflict. See Michael H. Armacost, U.S. Policy in the Persian Gulf and Kuwaiti Reflagging, Statement Before Senate Foreign Relations Comm., reprinted in 87 Dep't of State Bull. No. 2125, Aug. 1987, at 78, 79.

61. See Chemical Arms Control After the Paris Conference, supra note 25, at 4. Similarly, American willingness to provide modern Stinger anti-aircraft missiles to rebel forces in Afghanistan, Angola, and Chad has aroused concerus that the deadly technology could spread to other states or possibly to terrorists. See Cooper, Sandza \& Cullen, A Busy Swarm of Stingers, Newsweek, Nov. 23, 1987, at 44, 44.

The Soviet Union recently removed nuclear weapons from its southern republics, where they might more easily have fallen into the hands of dissident or nationalistic forces. See Wines, Soviets Are Said to Pull Nuclear Arms From Some Restive Regions, N.Y. Times, June 23, 1990, at 4, col. 1; Soviets Shift A-Arms from Tense Regions, L.A. Times, June 23, 1990, at A4, col. 4. But see Soviets Deny Shifting A-Weapons, L.A. Times, June 27, 1990, at A10, col. 5 (Soviets claim no such shifts had occurred). 
sored terrorists; the dispersal of more sophisticated types of weapons will only exacerbate the existing strains. ${ }^{62}$

Finally, the developed states are jeopardized in a more subtle, but perhaps more profound way, as the spread of modern weaponry reduces their ability to use, or credibly to threaten to use, military force in legitimate contexts, such as the assistance to self-determination and the resistance to aggression. As all states become more imperiled by the spread of sophisticated weaponry, each will lose a measure of its autonomy, having to live with the fear that any untoward national policy might provoke deadly, unanticipated retaliation from some quarter. ${ }^{63}$

The wealthy states will not be able to counter these diverse future threats through any of the usual techniques that have ensured their security in the past. Tactics such as simply procuring additional hardware, ${ }^{64}$ writing more treaties of alliance, ${ }^{65}$ or propounding familiar theories of deterrence and strategy, ${ }^{66}$ which may have worked in the

62. The United States Central Intelligence Agency is becoming particularly concerned about terrorists obtaining stockpiles of chemical and biological weaponry because those arms do not require the same degree of technological sophistication as nuclear explosives, and because they are so easy to transport with low risk of detection. See Nuclear and Missile Proliferation, supra note 37, at 20-21 (testimony of CIA director William Webster).

63. See Nolan \& Wheelon, supra note 38 , at 40 .

64. The Bush administration has signaled its intention to use the American stockpile of chemical weapons as a "bargaining chip" in two ways in future disarmament negotiations. First, the United States will destroy $80 \%$ of its existing CW devices even prior to conclusion of a comprehensive international agreement, but will retain the remaining $20 \%$ "to have some leverage" to induce others to reduce too. See Devroy, Bush Says Strategic Arms Pact Likely Next Year, Wash. Post, Sept. 28, 1989, at A4, col. 6 (quoting President Bush). Second, even under the anticipated treaty, the United States will seek to retain two percent of its chemical arms to provide an incentive to hold-out states to become parties to the convention. See Institute for Defense and Disarmament Studies, Arms Control Reporter, Apr. 1990, at 704.B.422. It is possible, however, that these types of "incentives" will backfire, driving states away from the flawed treaty regime, rather than into it.

65. Networks of alliances, various types of security assurances (promises never to use nuclear weapons against specified states, or promises to come to the aid of states attacked by nuclear weapons), and other ancillary security measures often have been advanced to help deal with the dangers of proliferation by enhancing states' sense of security and removing some of the fears that might otherwise prompt them to pursue deadly new arms. See V. Utgoff, Neutralizing the Value of Chemical Weapons: A Supplement to Cbemical Weapons Arms Control 1 (Atlantic Council of the United States Occasional Paper 1989) (on file with Columbia Law Review). None of these strategies, however, has proven sufficient to deal with the threat of the spread of advanced weaponry, and there is little prospect that they will become dramatically more effective in the future. See D. Fischer, The International Non-Proliferation Regime 1987, at 46-49 (U.N. Institute for Disarmament Research 1987).

66. See generally The International Politics of Deterrence (B. Buzan ed. 1987) (presenting variety of perspectives on international logic and practice of deterrence theory in various settings).

The superpowers' retention of significant stockpiles of nuclear and other weapons 
Cold War era, will be largely unavailing in the future age. Instead, some new types of security arrangements will have to replace those that sufficed for a generation to deal with the "old," inexorably bipolar, kinds of confrontations. The developed states, in short, need multilateral arms control, encompassing all states. ${ }^{67}$ To achieve this symmetric reduction in global military capacity, they need the cooperation of the developing world-real, voluntary cooperation this time, not the byproduct of superpower hegemony.

\section{The Need for Development Assistance}

These days, economic conditions are tough all over. Every state is grappling with the challenges of budgetary limitations, demands for increased domestic social services, and mounting international obligations. There are many legitimate claimants for the public largess, and no shortage of projects toward which increased funding usefully could be directed. 68

But the need for development ${ }^{69}$ assistance to the third world is of a deeper, more profound nature; it is a moral and economic imperative, not just something vaguely placed on a "wish list" of projects that would be nice to attend to some day. The gap between the wealthy and the poor states continuously widens; statistics regarding average life expectancy, per capita income, literacy, and other indicia of human dignity consistently reflect a world in which pockets of relative wealth are

will, of course, continue to help deter other states from launching attacks against them. But analysts now question the extent to which the threatened first use of nuclear weapons-with the profound dangers such a course would unleash upon the entire planetstill serves as a credible response to the use of conventional or chemical attack. See Bundy, Halperin, Kaufmann, Kennan, McNamara, O'Donnell, Sigal, Smith, Ullman \& Warnke, Back from the Brink, Atlantic, Aug. 1986, at 35, 35.

67. Of course, the developed states will have to accept a greater measure of disarmament for themselves too. They cannot plausibly argue that pursuit of advanced weaponry is acceptable for some states but not for others; as long as the leading military powers continue to act as if their security depends upon possession of chemical, nuclear, and other arms, it is not surprising that the developing states continue to harbor similar ambitions and strategies. See Deger, The United Nations International Conference on the Relationship Between Disarmament and Development, 1988 SIPRI Y.B., supra note 20 , at $517,524-25$.

68. See Matlack, Domestic Lobbies Trying to Cash In, 22 Nat'l J. 884 (1990) (identifying numerous domestic American agencies and interests that have suffered funding cutbacks in recent years and are now competing for sbares of the federal budget); see also Beilenson, Never Give Money Away to Anyone, Nat'l Rev., July 24, 1981, at 841, 841 (arguing that United States should not allocate public funds for foreign charitable aid when America's own budget deficit is so large).

69. The concept of "development" is an elusive one, embracing social and economic changes to raise per capita income and improve standards of living. Rough statistical indices of the standard of living can be found in average life expectancy, literacy, infant mortality, nutritional availability, and other considerations. See A Programme for Survival, supra note 2, at 23, 48; Deger, supra note 67 , at 519 . 
sustained in the midst of crushing poverty, hunger, and deprivation. ${ }^{70}$ Local and regional arms races swallow resources unproductively and jeopardize the fleeting opportunities for achieving real growth and stability. ${ }^{71}$

Outside assistance is required to help the poor states crawl out from their current desperate situation; few, if any, would be able to transform themselves into modern industrialized societies without substantial infusions of money, know-how, and management advice. ${ }^{72}$ Even a relatively modest amount of foreign intervention, if skillfully planned and consistently maintained, could have a sizeable catalytic impact; in subsistence economies, a dollop of assistance can be stretched surprisingly far if conditions are favorable. ${ }^{73}$

70. Statistics about the depth and pervasiveness of poverty in the third world are hard to contemplate. See Final Document, Int'l Conference on the Relationship Between Disarmament and Development, New York, Aug. 24-Sept. 11, 1987, I 26, reprinted in [1987] 12 U.N. Disarmament Y.B. 372, 375, U.N. Sales No. E.88.IX.2 (1987) ("In developing countries, it has been estimated that close to 1 billion people are below the poverty line, 780 million people are undernourished, 850 million are illiterate, 1.5 billion have no access to medical facilities, an equally large number are unemployed, and 1 billion people are inadequately housed."); see also P. Harrison, The Third World Tomorrow: A Report from the Battlefront in the War Against Poverty 108-09, 212, 256 (2d ed. 1983) (describing destitution of poverty in developing countries); A Programme for Survival, supra note 2, at 30-32, 49-50, 54-58 (gap is immense between wealthy and poor states in all areas of human well-being); Deger, supra note 67, at 517-19 (developing world contains over three-quarters of world's population, but less than one-fifth of its total production, consumption, and investment of wealth).

71. See L. Spector, supra note 29, at 11-12 (developing countries have profound interest in avoiding regional arms races that could sap their resources and erode global norm against spread of threatening weaponry); A Programme for Survival, supra note 2, at 14,117-18 (noting economic tradeoffs between military and social spending, such as cost of one modern tank equalling cost of 1000 school classrooms or of improved storage facilities for 100,000 tons of rice); Adeniran \& Stoffer, Africa and Arms Control: A New Perspective, 17 Stan. J. Int'l L. 163, 164-65 (1981) (indigenous arms producers and the influence of foreign suppliers often divert African states' attention from economic growth, causing them to pour scarce resources into wasteful military spending); Fontanel, The Main Economic and Political Aims of an International Disarmament Fund for Development, in U.N. Inst. for Disarmament Research, Establishment of an International Disarmament Fund for Development 159, 163-64 (1984) [hereinafter International Disarmament Fund] (spending on military items and activities does not promote economic growth as much as other allocations of national budgeting would).

72. See P. Harrison, supra note 70, at 326-28; Bota, Preface, in International Disarmament Fund, supra note 71, at 5; see also Lewis, Poorest Countries Seek Increases in Aid, N.Y. Times, July 3, 1990, at A3, col. 4 (42 poorest states ask world's richest nations for debt relief, aid, and markets for their produce). But see P.T. Bauer, Reality and Rhetoric: Studies in the Economics of Development 43-47 (1984) (foreign aid does not help poor countries develop, but only disrupts patterns of economic growth that otherwise would evolve more productively); A Programme for Survival, supra note 2, at 126, 139 (developing countries themselves must take lead in devising strategies for economic growth).

73. See Dep't of Political and Security Council Affairs, U.N. Centre for Disarmament, Report of the Secretary-General, The Relationship Between Disarmament and Development 90, U.N. Doc. A/36/356 (1981) [hereinafter Disarmament and Develop- 
A substantial, regularized program of foreign aid, moreover, would advance the self-interest of the donor states of both East and West, as a strategic investment in future security and commerce. ${ }^{74}$ By promoting stronger local economies in developing states, the contributing state builds relationships with potential suppliers of some products and potential customers of others. ${ }^{75}$ By encouraging a more hopeful economic outlook, the developed world reduces some of the tensions and grievances that might promote the growth of totalitarian, and potentially aggressive, governments. ${ }^{76}$ By propping up debt-ridden econo-

ment] (an increase of five percent in aid to developing countries is indispensable minimum for acceptable economic growth there); Salam, What the Third World Really Needs, Bull. Atom. Scientists, Nov. 1988, at 8, 8-10 (noting how even relatively small programs of scientific and technological assistance can make a difference in developing countries); see also J. Baker, Imperatives of Economic Reform: Change in Soviet and East European Economies, Testimony Before House Ways and Means Committee, Apr. 18,1990 , reprinted in U.S. Dep't of State Current Policy No. 1270, at 1 (suggesting that American assistance can play important role in speeding Soviet Union and Eastern European states into political and economic reform).

74. The philosophical origins of the American foreign aid program can be traced to the post-World War II efforts to blunt Soviet expansionism and promote American business interests by strengthening the market economies around the globe. See Sewell \& Contee, Foreign Aid and Gramm-Rudman, 65 Foreign Aff. 1015, 1015 (1987).

75. See W.W. Rostow, Rich Countries and Poor Countries: Reflections on the Past, Lessons for the Future 116 (1987) (exports from developed states to developing states have increased dramatically in past two decades); Bureau of Public Affairs, U.S. Dep't of State, Gist: U.S. Prosperity and the Developing Countries 1-2 (Sept. 1989) (developing countries purchased $\$ 95$ billion worth of United States manufactured products in 1988 , about $40 \%$ of total American merchandise exports, and they supplied over half the United States imports of several critical primary products) (on file with Columbia Law Review). Economic progress, or the lack thereof, in the developing states can have a profound impact upon the American economy too. For example, when the world experienced a general economic downturn from 1980 to 1985, the developing states in particular suffered, and they purchased far fewer American and other goods on the global market. Over half of the decline in United States exports during this period resulted from decreased third world demand, and nearly 1.7 million American jobs-in industries ranging from heavy machinery to agriculture-were lost as a result of the developing states' recession. See Sewell \& Contee, supra note 74, at 1018-19; see also P. Harrison, supra note 70, at 151 (economic aid to developing countries will indirectly increase their purchases of donor's exports); Stanfield, Fixing Foreign Aid, 20 Nat'l J. 1223,1225 (1990) (evaluating proposals to link foreign aid with credits to American exporters). But see P.T. Bauer, supra note 72, at 54-55 (arguing that foreign aid does not generally increase recipient's purchases of donor state's exports).

76. See A Programme for Survival, supra note 2, at 16 ("While hunger rules, peace cannot prevail. He who wants to ban war must also ban mass poverty."); Bota, supra note 72, at 5; Sollie, Institutional, Technical and Political Aspects of an International Disarmament Fund for Development, in International Disarmament Fund, supra note 71, at 59, 86; Pipart \& Sada, The Establishment of an International Disarmament Fund for Development: The Regional Approach, in International Disarmament Fund, supra note 71, at 89, 132; Maynes, If the Poor Countries Go Under, We'll Sink with Them, Wash. Post, Sept. 18, 1983, at Cl, col. 1 (economic downturns in many developing countries in recent years may trigger a chain of violent revolutions comparable to those in Great Depression era, when violence overthrew democratic governments from Vietnam to Nicaragua). But see Sollie, supra, at 66 (in some instances, as in Iran under the 
mies, the capital-exporting states can help safeguard their own banking systems from collapse and protect the system of international finance. ${ }^{77}$ By underwriting economic growth, the donor may even ease pressures that might otherwise force local farmers and businesses into activities related to the drug trade. ${ }^{78}$

Nevertheless, these factors have not occasioned much international generosity-at least not nearly enough to make a sufficient dent in the problem. ${ }^{79}$ As long as the impulse for foreign aid is driven only by these rather evanescent considerations of charitable obligation or longrun self-interest, the instinct to give will not flourish. As Richard Gardner has observed, "The idea of international assistance to help the less developed countries develop their human and material resources ... has received declining real financial support in recent years, except where immediate security interests have been predominant." 80 "

Under these circumstances, foreign aid for economic development will continue to be a fringe item in national budgeting, provided only when the spirit moves the donor state, ${ }^{81}$ and it will never become a

Shah, ill-conceived and rash development may actually lead to increased social unrest at local, national, and international levels); Mearsheimer, supra note 10, at 46 ("democracies are every bit as likely to fight wars as are authoritarian states").

77. See Pipart \& Sada, supra note 76, at 131. But see P.T. Bauer, supra note 72, at 60 (opposing foreign aid used as policy tool to sustain capital exporting states' banks).

78. See Brooke, Peru Develops Plan to Work with U.S. to Combat Drugs, N.Y. Times, Jan. 25, 1991, at A2, col. 3; Gugliotta, Agencies' Spat Blocks Plan for Reducing Coca Crops, Wash. Post, June 27, 1990, at A17, col. 3; cf. Swardson, S. America Trade Plan Proposed, Wash. Post, Nov. 2, 1989, at A53, col. 6 (United States resistance caused demise of emerging multilateral coffee-trade treaty; resulting deadlock led to precipitous fall in world coffee prices, eliminating important alternative crop for farmers who might now cultivate coca (raw material used for making cocaine)).

79. In the early post-World War II years, foreign aid was a large and popular part of national budgets. By 1951, the Western democracies were allocating almost $1 \%$ of their gross national product to that purpose. Later, however, aid levels declined precipitously. See infra note 80 and accompanying text; infra note 84 . In 1971 , the United Nations set a target for each developed state to allocate $0.7 \%$ of its gross national product to foreign aid, but few states have even attempted to sustain that level, and none has consistently reached it. See Disarmament and Development, supra note 73, at 30-31; P. Harrison, supra note 70, at 310-12, 324.

Foreign aid has become among the least popular items in American budgeting, and an increasing proportion (66\% in 1987) of the annual aid package consists of military aid (equipment, training, etc.) rather than economic assistance that would be useful for development. See Sewell \& Contee, supra note 74, at 1022; Stanfield, supra note 75, at 1224; Zintl, The Cost of Friendship, Time, Feb. 11, 1985, at 33.

80. Gardner, supra note 1 , at 32; see also Maynes, supra note 76, at C1, col. 1, C2, col. 5 (American officials suffer from "policy fatigue" toward economic development, and "any appeal to the humanitarian instinct of the American people and particularly the American policy community is likely to fail").

81. The United States provides foreign aid to 102 countries, but in most instances the package provided is far too small to make a major dent in the problems. The United States has allocated to foreign aid one of the lowest percentages among Western countries, while spending $6 \%$ of its national income on defense-higher than any other 
reliable, sizeable program of international transfers. ${ }^{82}$ For example, at the most recent major international meeting on the subject, the September 1990 Second United Nations Conference on the Least Developed Countries, the major donor states effectively resisted efforts to establish a worldwide goal (even a goal without any binding legal commitments behind it) of providing to the poorest countries official development assistance equivalent to 0.20 of one percent of the donor states' respective gross national products (GNP). ${ }^{83}$ Without some stronger type of legal obligation, therefore, the third world simply cannot count on adequate levels of assistance from the developed countries. ${ }^{84}$

Western nation. See Obey \& Lancaster, Funding Foreign Aid, Foreign Pol'y, Summer $1988,141,149-50$.

For fiscal year 1991, the United States will supply a total of $\$ 15.4$ billion in foreign aid, down from $\$ 20.9$ billion in 1985. As in previous years, the bulk of the funds (almost one-third of the total) will go to Israel and Egypt, with the new governments of Eastern Europe also receiving substantial funding, thus leaving less support left over for the poorest developing countries. See Doherty, A Reluctant Congress Passes $\$ 15$ Billion Assistance Bill, Cong. Q. Weekly Rep., Nov. 3, 1990, at 3730, 3730-31. In recent years, less than one-quarter of United States bilateral development assistance has been programmed for the lowest-income countries. See Obey \& Lancaster, supra, at 149.

The Soviet Union, too, has put domestic concerns ahead of foreign aid: in 1989, Soviet military assistance to third world countries fell to $\$ 17$ billion, down from $\$ 19$ billion the year before, and leading officials have indicated that Moscow will be placing less emphasis on its relationships with developing countries due to the demands of political reform in Eastern Europe and inside the U.S.S.R. See Soviets Plan to Review Military Aid, Wash. Post, May 27, 1990, at A27, col. 1.

Even Sweden, probably the leading state in donating foreign aid and promoting international cooperation for development, has experienced periods when domestic economic conditions caused it to reduce its international giving. See Sollie, supra note 76, at 75 .

82. Multilateral institutions such as the International Monetary Fund and World Bank also have played a major role in assisting poor countries in economic development, and the quantity of funds made available through these organizations has increased. See Rowen, Third World Debt Problems Worsen, Report Shows, Wash. Post, Sept. 18, 1989, at A22, col. 1; Stevens, Pressure on World Bank to Save the World, N.Y. Times, Sept. 11, 1989, at A9, col. 1. These resources, however, are far from sufficient to meet the developing countries' needs, and political wrangling over the allocation system has also troubled many of the programs. See Rowen \& Mufson, Rich Nations Back Boost In Aid to Poor Countries, Wash. Post, May 7, 1990, at A20, col. 1.

83. See Greenhouse, Poor Nations Get Unspecified Pledge of More Aid, N.Y. Times, Sept. 16, 1990, at 4, col. 1. The first U.N. conference, in 1981, had established a goal of 0.15 of $1 \%$ of GNP for international assistance directly targeted toward the neediest recipient states, and some Scandinavian countries and Holland have already exceeded that level. The United States, however, has provided only 0.04 of $1 \%$ as official development aid to the poorest developing countries, and Japan (the second largest donor in absolute terms) has given only 0.07 of $1 \%$. See id.; see also supra note 81 (describing overall levels of foreign aid, beyond development assistance accorded to poorest countries).

84. Cf. Sewell \& Contee, supra note 74, at 1018 ("Unfortunately, development progress has virtually halted since 1980 . Mounting debt, falling commodity prices and sluggish global trade flows have devastated many Third World economies."); Dewar, Voices 


\section{The NeEd for Stronger International Legal Institutions}

In this Part, we consider some of the ways in which future arms control agreements are likely to be systematically different from-and even more challenging than-the generation of treaties already negotiated. We also evaluate the world's existing treaty mechanisms for coping with international problems and disputes, and assess how those institutions repeatedly have failed to deal effectively with even the relatively simple demands of the current generation of disarmament issues. Finally, we suggest the various approaches that individual states might take in evaluating arms control proposals, including our own, in deciding whether to join a new disarmament regime.

\section{A. Future Directions in Arms Control}

The next wave of arms control agreements will include certain characteristics that impose still greater burdens upon the negotiators and implementors, intensifying the existing shortcomings. The first characteristic is the participation of so many states in the bargaining process, states who will proceed largely independently, with less automatic deference to the superpowers than in earlier years. ${ }^{85}$ Agreement between the United States and the Soviet Union is still a critical element, ${ }^{86}$ of course, but increasingly the leadership in the disarmament negotiations arises from other sources, as the rest of the world shows less patience with American or Soviet hesitancy. ${ }^{87}$

Second, a related feature is the growing equality of the parties; fu-

Rise as Foreign Aid Does Not, Wash. Post, Feb. 18, 1990, at A50, col. 1 (there are many claimants for increased foreign aid, but the total pool of available support is not growing); Goshko, Old Allocations, New Order Hard to Reconcile, Wash. Post, May 17, 1990 , at A1, col. 1 (same).

85. For many earlier multilateral arms control agreements, the negotiation process began with an essentially bilateral phase, as the United States and Soviet Union addressed and resolved all the critical issues on a one-to-one basis, and then presented their joint product to the international community for possible modification and approval by as many states as possible. This was the process that produced the BWC, the Outer Space Treaty, the Seabeds Arms Control Treaty, and the Non-Proliferation Treaty. See Texts and Histories of Negotiations, supra note 19, at 53, 90-92, 108, 129-31. The Treaty of Tlatelolco, on the other hand, was negotiated essentially among the Latin American states, with countries outside the region playing a smaller role. See Texts and Histories of Negotiations, supra note 19, at 64-65.

86. Cf. Goldblat, Multilateral Arms Control Efforts, 1987 SIPRI Y.B., supra note 8, at 383, 383 (in 1986, Committee on Disarmament failed, for ninth consecutive year, to reach agreement on any item on its negotiating agenda despite efforts of international community, due to arms control impasse between United States and Soviet Union).

87. Cf. Neidle, supra note 19, at 21 (nonaligned states "are no longer prepared to play the role of neutral catalysts seeking patiently to promote progress by more important' powers"). As noted by Abram Chayes, American chair of the Technical Coordinating Committee of the International Nuclear Fuel Cycle Evaluation:

if we want a regime governing the terms and conditions of international access to nuclear fuel, facilities and technology, it will have to be a regime that is internationally formulated and has the concurrence of all major affected interests. 
ture treaties are very unlikely to adopt the model of the NPT, which ratified a permanent legal distinction between those states that already possess nuclear weapons and those that do not. ${ }^{88}$ Instead, the next generation of treaties will insist that the parties' respective rights be in parity and that their corresponding obligations be parallel, if not rigidly identical. ${ }^{89}$

A third probable aspect of future treaties will be their attempt to focus attention on real disarmament, rather than on partial or interim measures that tend simply to confirm in writing the parties' previous independent national intentions. ${ }^{90}$ Increasingly, states have come to

The day when the United States or any other country could impose its will on these matters is over.

Dombey, International Agreements on Nuclear Weapons, Bull. Atom. Scientists, Mar. I982, at $36,38$.

More starkly, the initiative for calling the recent international conference to consider amending the LTBT to expand it into a comprehensive ban on all nuclear tests came from a collection of nonnuclear weapons states. Indonesia, Mexico, Peru, Sri Lanka, and Yugoslavia took the lead in galvanizing world public opinion on the issue, over the opposition of the United States. See Baker, Nations Plan Nuclear Test Ban, Def. News, Aug. 8, 1988, at 4.

88. The "basic bargain" of the NPT committed the "nuclear weapons states" (NWS) (those that had already conducted a nuclear explosion by Jan. I, 1967) to share the civilian benefits of nuclear power and to negotiate future restraints on their nuclear arms race. In return, the "non-nuclear weapons states" (NNWS) agreed never to acquire their own nuclear weapons. This exchange, therefore, legitimates the retention of an important military capability by one group of states, while denying that same power to others. This aspect of the treaty was regarded, even by some of the negotiators for the nuclear weapons states, as "one of the 'greatest con games of modern times.' "W. Epstein, The Last Chance: Nuclear Proliferation and Arms Control 118 (1976).

Many NNWS-including some that have no lingering nuclear aspirations of their own-have criticized this aspect of the NPT as discriminatory, and have sought a more even-handed solution to constrain the nuclear arsenals of all states simultaneously. See D. Fischer, supra note 65, at 29; Goldblat, supra note 21, at 370.

89. In the negotiations toward a comprehensive chemical weapons disarmament convention, competing possibilities for asymmetric reductions to be made by different states have been advanced, without much general acceptance. The United States has indicated that it will retain a small but significant $\mathrm{CW}$ arsenal until all other states capable of producing chemical arms have adhered to the treaty and dismantled their stockpiles. See supra note 64 . France, on the other hand, has proposed that the nations now possessing large CW stockpiles should be required to dismantle them as soon as possible, while the parties with lesser chemical weapons investments should be able to sustain them, as a security hedge, for up to ten years. See Marshall, Progress on a Chemical Arms Treaty, 238 Science 471,472 (1987). Neither approach is likely to be nearly as popular as a treaty calling for parallel reductions by all participants.

90. Some early multilateral arms control agreements were not very significant militarily because they merely confirmed the parties' separate intentions to refrain from pursuing certain weapons options that seemed expensive, unreliable, or impractical for other reasons. Thus, a primary motivation for the BWC was the American conclusion that biological weapons had very low military utility in any event. See Texts and Histories of Negotiations, supra note 19, at 129-32. Similarly, no states yet have the capacity to manipulate the environment as a tool of warfare or to exploit the seabed for important military advantage, so the Environmental Modification Convention and the Seabeds 
realize that halfway measures are inadequate-they channel or redirect an arms race, but do not preclude it. Future agreements thus are likely to be more militarily meaningful than their predecessors, imposing constraints that significantly impinge upon defense plans and options that states might otherwise exercise. ${ }^{91}$

Associated with this feature will be even greater concern with the intrusiveness of the verification arrangements, as the parties demand and accept augmented procedures for ensuring compliance. ${ }^{92}$ The Intermediate Nuclear Forces (1NF) ${ }^{93}$ and Conventional Forces in Europe (CFE) treaties ${ }^{94}$ and the nascent. $\mathrm{CW}$ treaty ${ }^{95}$ are the prototypes and leading edges of this trend, demonstrating a punctilious concern with

Arms Control Treaty were relatively easy to conclude, since they did not close off any viable short-term military possibilities. See Texts and Histories of Negotiations, supra note 19, at 107-10,211-13. The long-term value of such treaties sometimes may prove more considerable, however. For example, the Outer Space Treaty bans the placement into orbit of nuclear weapons. Outer Space Treaty, supra note 23, art. IV, 18 U.S.T. at 2413 , T.I.A.S. No. 6347 , at 4,610 U.N.T.S. at 208 . Within 15 years of its conclusion, scientists had begun work on a variety of space-based laser weapons driven by nuclear explosions, but the treaty stands as an important legal impediment to the deployment of any such "Strategic Defense Initiative" devices. See A. Sherr, Legal Issues of the "Star Wars" Defense Program 21 (Lawyers Alliance lssue Brief 3, 1984).

91. The BWC, see supra note 22 , and the INF Treaty, see infra note 93 , were the first arms control accords to eliminate totally an entire category of weapons, rather than simply to restrict the size of the residual arsenals that the powers could retain. The chemical weapons treaty that is currently under negotiation will have a similar character, seeking to abolish entirely the chemical weapons capabilities of participating states. See Preliminary Structure of a Convention on Chemical Weapons, preamble, art. I, reprinted in Conference on Disarmament, Report of the Ad Hoc Committee on Chemical Weapons to the Conference on Disarmament, CD/I033, Aug. 1990, app. I, at 19, 20-22.

Unlike its predecessors in the field of strategic arms control, the nascent START agreement will contain substantial reductions in the superpowers' modern intercontinental-range nuclear arms, rather than merely capping the growth of the arsenals. See Arms Treaty: The Outlook, N.Y. Times, June 2, 1990, at 4, cols. 5-6.

92. The international community has long recognized that verification is an integral part of any sound arms control agreement. A preeminent element in all recent multilateral negotiations has been the necessity for establishing procedures through which all parties to a disarmament treaty could be confident that the obligations were being fully implemented by all participants. See [1988] 13 U.N. Disarmament Y.B. 121, I36, U.N. Sales No. E.89.IX.5 (1988).

93. The INF Treaty (Treaty on the Elimination of Intermediate-Range and ShorterRange Missiles, Dec. 8, 1987, United States-U.S.S.R., 27 I.L.M. 90 [hereinafter INF Treaty]) contained verification provisions of unprecedented intrusiveness, mandating on-site inspections at 118 locations inside the United States, the Soviet Union, and their respective European allies over a period of 13 years. See id., art. V, 27 I.L.M. at 95-96; Dean, The INF Treaty Negotiations, 1988 SIPRI Y.B., supra note 20, at 375, 387.

94. The Treaty on Conventional Armed Forces in Europe includes a detailed Protocol on Inspection, providing for extensive on-site inspections, including surprise inspections, throughout Europe. See CFE Treaty, supra note 7, 30 I.L.M. at 52-66.

95. The forthcoming chemical weapons convention is now under negotiation within the 40-member Conference on Disarmament, a United Nations affiliate charged with responsibility for developing multilateral arms control initiatives. The current draft "rolling text" of an agreement has evolved over several years of deliberations; it now 
inspection privileges and manifesting the negotiators' abilities to elaborate the necessary verification provisions in careful text with unprecedented rigor. ${ }^{96}$ The world will never again return to the era when important arms control accords contained no verification provisions whatsoever, ${ }^{97}$ or even to the more recent era when "national technical means of verification" alone were deemed sufficient to monitor compliance. ${ }^{98}$ Instead, future arms control accords inexorably will expose many more hitherto private details about the parties' defense structures, military-industrial capacity, and private businesses..$^{99}$

Further, it is predictable that many future multilateral arms control treaties will include provisions establishing interuational implementation bodies to supervise an international inspectorate and to adjudicate

reflects substantial areas of agreement, but several significant barriers still remain. See Conference on Disarmament, supra note 91.

96. The chemical weapons convention will evoke a massive system of inspections and reporting requirements, as the international apparatus gains mandatory access to chemical weapons production and storage facilities (and also to other, civilian plants that could be converted to weapons purposes). See Preliminary Structure of a Convention on Chemical Weapons, arts. IV, V, reprinted in Conference on Disarmament, supra note 91, app. I, at 29-31, 32-34.

97. The Geneva Protocol, supra note 23, the LTBT, supra note 20 , and the BWC, supra note 22, were all silent regarding procedures for monitoring the parties' performance of their obligations, and each state implicitly undertook to perform unilaterally the degree of monitoring that it considered appropriate.

98. Some important treaties have relied exclusively or mainly upon verification by "national technical means" (NTM). The SALT I Interim Agreement on the Limitation of Strategic Offensive Arms, May 26, 1972, United States-U.S.S.R., art. V, 23 U.S.T. 3462, 3465, T.1.A.S. No. 7504, at 4 [hereinafter SALT I Interim Agreement]; the ABM Treaty, see supra note 4, art. XIl, 23 U.S.T. at 3443, T.1.A.S. No. 7503, at 9-10; and the SALT II Treaty (Treaty on the Limitation of Strategic Offensive Arms), June 18, 1979, United States-U.S.S.R., art. XV, 18 I.L.M. 1112, 1134-35 (signed but not ratified) [hereinafter SALT II Treaty], contain virtually identical language recording the parties' agreement to use NTM in compliance with international law, not to interfere with the other party's NTM, and not to use deliberate concealment measures that impede verification by NTM.

The United States and Soviet Union have not expressly defined NTM or identified the systems that are included within it, but it is generally taken to comprise photoreconnaissance satellites, ground based radars, long-range seismometers, and other comparable equipment. See Richelson, Technical Collection and Arms Control, in Verification and Arms Control I69, 169 (W. Potter ed. I985).

99. Military facilities and activities will of course continue to be of the utmost concern in future arms control agreements, but as the weapons being regulated become smaller, more mobile, and capable of being produced and stored in ordinary-appearing commercial buildings, the arms control inspection regime will of necessity begin to intrude increasingly into business premises and even homes. Chemical weapons, for example, may be manufactured in a great many facilities that are now producing pharmaceuticals, plastics, fertilizers, and the like, so an effective verification mechanism will have to expose those operations. Cf. Tanzman, Constitutionality of Warrantless On-Site Arms Control Inspections in the United States, 13 Yale J. Int'l L. 21, 29-66 (1988) (surveying legal issues arising from contemplated inspection processes of chemical weapons convention). 


\section{(or at least to find facts) after suspicions of treaty violations. ${ }^{100}$}

Finally, future treaties are likely to require a substantial degree of international consensus in order to enter into force, ${ }^{101}$ as states will be reluctant to accept important military obligations in isolation, without corresponding limitations being imposed upon rivals. A typical multilateral agreement might specify that it will not become operational until some very high percentage of the nations of the world (including, perhaps, all militarily significant countries ${ }^{102}$ ) adheres. ${ }^{103}$ Alternatively, an

100. The ABM Treaty established a Standing Consultative Commission, see ABM Treaty, supra note 4, art. X11I, 23 U.S.T. at 3444-45, T.I.A.S. No. 7503, at 10-11, and the INF Treaty established a Special Verification Commission, see INF Treaty, supra note 93, art. XIII, 27 I.L.M. at 97, to facilitate the parties' discussion of compliance issues. However, these institutions were not created as independent organizations; each government controls its own delegation and all decisions require unanimity, so the commissions operate more like negotiating delegations. The forthcoming chemical weapons convention, in contrast, would create an international bureaucracy endowed with a degree of autonomy. This body would, to some extent, develop its own powers and functions outside the control of individual member states. See Preliminary Structure of a Convention on Chemical Weapons, art. VIII, reprinted in Conference on Disarmament, supra note 91 , app. I, at 38-46.

101. Some multilateral arms control agreements, such as the Environmental Modification Convention, have required specified threshold numbers of participants before the treaty would enter into force for any state. See Environmental Modification Convention, supra note 23 , art. IX.3, 31 U.S.T. at 340, T.I.A.S. No. 9614, at 8, 1108 U.N.T.S. at 155 (requiring deposit of instrument of ratification with Secretary-General of U.N. by 20 governments). Others, such as the Geneva Protocol, have not defined a required number of initial parties. See Geneva Protocol, supra note 23, 26 U.S.T. at 575, T.I.A.S. No. 8061, at 5, 94 L.N.T.S. at 7I; see also Antarctic Treaty, supra note 23, art. XIII, 12 U.S.T. at 800 , T.I.A.S. No. 4780 , at 7, 402 U.N.T.S. at $82-84$.

102. For example, the chemical weapons treaty that is now under negotiation was originally contemplated to include a comprehensive, permanent ban on all chemical weapons and related activities, but the United States has recently taken the position that until the treaty is joined by all states that are capable of producing chemical weapons, the United States will retain a small chemical weapons stockpile as a reserve deterrent. See Feinstein, Mystery Surrounds 'Fire' at Libyan Chemical Plant, Arms Control Today, Apr. 1990, at 26. The CFE Treaty will enter into force only when ratified by all 22 of its negotiating states. See CFE Treaty, supra note 7, art. 22, 30 I.L.M. at 23.

Other multilateral arms control negotiations have provided that the treaty will not enter into force until it has been ratified by all three of the major powers (typically, the United States, the Soviet Union, and the United Kingdom, who often acted as negotiators and depositaries). See the LTBT, supra note 20, art. III.3, 14 U.S.T. at 1318, T.I.A.S. No. 5433, at 6, 480 U.N.T.S. at 47 (requiring three original parties); the Outer Space Treaty, supra note 23, art. XIV.3, 18 U.S.T. at 2419, T.I.A.S. No. 6347, at 10, 610 U.N.T.S. at 211 (requiring those three, plus at least two more); and the NPT, supra note 21 , art. IX.3, 21 U.S.T. at 492, T.I.A.S. No. 6839, at 10, 729 U.N.T.S. at 174 (requiring those three, plus forty others).

103. See Thee, Modalities for the Establishment of an International Disarmament Fund for Development: Vision and Political Feasibility, in International Disarmament Fund, supra note 71 , at 48 ; cf. Marshall, supra note 89 , at 473 (very restrictive chemical weapons treaty might drive away 12 to 15 ambivalent nations, and some leading officials conclude that chemical weapons agreements joined by only a few big countries would hardly be worth the effort). 
agreement might include clauses under which it would automatically terminate unless acceded to by a designated number of countries, or by specified individual countries, within a certain number of years. ${ }^{104}$

\section{B. Current Shortcomings}

All of these new features will place additional burdens upon a system that has to date proven itself ineffective for coping with even the relatively lower level of demands posed by existing arms control accords. These defects have been revealed in existing arms control regimes in each of the three critical phases of a treaty's life: negotiation, implementation, and enforcement.

1. Negotiation, Signature, and Adherence. - To date, there has simply been too little incentive for all the important states to participate in the negotiations, to help shape the treaty regime, to join it once it has been created, and to sustain membership throughout the life of the agreement. States naturally ask "What's in it for me?" and the international community has not regularly been able to provide a sufficiently tempting response.

The participants in multilateral arms control are, after all, a diverse lot, with radically different interests, fears, and capabilities; it is always difficult to fashion a mutually acceptable package of trade-offs that is even-handed without being procrustean. In some states, a natural affinity for the objectives of arms control-coupled, perhaps, with intense lobbying from allies and other champions of the treaty-will suffice, but for others, the international political "credit" tbat they earn from participation in the treaty will not be worth much, especially if their important regional rivals remain aloof.

Each arms control regime has had to deal-none very successfully- with "problem countries," those that hold out against an emerging consensus and thereby undercut it. ${ }^{105}$ In some instances a "free

104. The trilateral (United States, Soviet Union, and United Kingdom) negotiations toward a comprehensive nuclear test ban treaty from 1977-1980 proceeded without the participation of two other acknowledged nuclear weapons states, France and the People's Republic of China (PRC). The negotiators hoped eventually to develop a formula for drawing those two powers (as well as all other countries) into the treaty regime when it was completed, knowing that a test ban that embraced only three of the nuclear weapons states was not likely to be durable. See H. York, Making Weapons, Talking Peace: A Physicist's Odyssey from Hiroshima to Geneva 301-02 (1987).

105. For example, a major concern regarding the NPT - which has been joined by 140 states-concerns the proliferation dangers posed by "nuclear threshold countries," such as Argentina, Brazil, India, Israel, Pakistan, and South Africa, that have refused to adhere to the treaty and that conduct significant nuclear activities and operate facilities capable of covertly producing weapons-grade materials. See D. Fischer, supra note 65, at 17 ; Goldblat, supra note 53 , at 358 .

Similarly, the LTBT has not been signed by, inter alia, France, PRC, and Cuba, and other countries such as Pakistan and Argentina waited over 20 years between signing the treaty and ratifying it. See Texts and Histories of Negotiations, supra note 19 , at 44,48 , 50; L. Spector, supra note 29 , at 312. 
rider" of this sort may gain the benefits of others' sacrifices-it shares the security advantages that accrue when its neighbors reliably pledge to foreswear certain threatening military hardware-without paying the price of assuming offsetting restraints itself. ${ }^{106}$ In other instances the holdout may have only the illusion of a free ride, as the cost of sustaining the military option makes it more a burden than a benefit ${ }^{107}-$ but the practice can nonetheless jeopardize other states' continued fealty to the less-than-complete treaty regime. ${ }^{108}$ And in many instances, the potential holdouts have found it advantageous to "tease" treaty supporters, by wavering indefinitely on the precipice of pursuing the dangerous weapons, in the hopes that fear will eventually cause the arms controllers to "up the ante" and provide even greater benefits, adjunct to those of the treaty itself, to lure the threshold states into the fold. 109

Worse than that, inclusion in arms control agreements in the modern era has become quite expensive financially for the parties, ${ }^{110}$ and significant budgetary disincentives have emerged that actually serve to

106. See W. Baumol \& A. Blinder, Economics: Principles and Policy 792 (3d ed. 1985); cf. Treverton, Managing the Alliance Politics of Multilateral Arms Control, in Arms Control: The Multilateral Alternative, supra note 18, at 73, 75-78 (describing opportunities for "free riding" by allies, who might rhetorically support calls for grandiose disarmament proposals, knowing that United States will inject reality necessary to prevent excesses).

107. Nuclear weapons and other advanced arms can be very expensive to develop and deploy, and can incite local arms races in which higher spending by jealous or fearful neighbors provokes still greater commitments of resources on all sides. See, e.g., Kennedy, Nonproliferation as a Fundamental Policy Goal, 87 Dep't St. Bull. No. 2129, Dec. 1987, at 77, 77-80; see also Deger \& West, Introduction: Defence Expenditure, National Security and Economic Development in the Third World, in Defence, Security and Development 1 (S. Deger \& R. West eds. 1987) (noting tradeoff for developing countries between spending national income on military affairs or on social needs and economic development).

108. The Treaty of Tlatelolco, supra note 23 , art. xxviii, 634 U.N.T.S. at $352-54$, for example, has elaborate procedures requiring all the states in Latin America to join the treaty before it enters into force for any of them, but also permitting states to waive that condition in favor of immediate effectiveness. To date, 23 states have filed the waiver; Brazil and Chile have ratified the treaty but not waived the condition; Argentina has signed but not ratified; and Cuba alone among the eligible states has refused to sign the treaty. See D. Fischer, supra note 65 , at 30.

109. The United States, for example, has provided immense military and other assistance to Pakistan, which has long sustained a thinly veiled nuclear weapons development program. American officials were motivated in part by the hope that if Pakistan received sufficient aid to feel confident about its conventional military forces, it might have less incentive to procure nuclear arms. However, this American aid-not being tied to specific actions on the part of Pakistan-seems to have afforded the United States precious little leverage. See Goldblat, supra note 21, at 380-81; Note, Nuclear NonProliferation for the 80s: Carrot and Stick Policy Reexamined, 13 Brooklyn J. Int'l L. 25, 42-47 (1987).

110. Of course, some states can save money by refraining from building and deploying the weapons that are regulated by a disarmament agreement, see supra note 107. But other states would not have proceeded with those weapons programs anyway, 
drive potential states away from participation. ${ }^{111}$ The high-technology verification systems, based on satellites or other devices, are frightfully expensive. 112 The cost of mounting and of hosting frequent on-site inspections also can be substantial.113 Compliance with the detailed recordkeeping and security demands of treaties will consume personnel and other resources that could usefully be dedicated elsewhere. ${ }^{114}$ And Will Carpenter and Kyle Olsen of the Chemical Manufacturers Association have identified a novel additional cost element that has been added

so the treaty produces no tangible savings for them, yet they will still have to bear their shares of the costs of the verification apparatus.

111. For example, the safeguards regime of the NPT is applied more rigidly against states that are parties to the treaty than against states that hold out. For parties, the safeguards are applied on all nuclear activities, whereas for nonparties, safeguards apply only to the particular items being imported, and indigenously developed capacities may remain unencumbered. This discrimination may not be a major cost element driving states away from the arms control regime, but it certainly is an incentive that is pointed in the wrong direction. See Goldblat, supra note 21, at 373.

112. The new generation of United States "Lacrosse" satellites, equipped with synthetic-aperture radar, permitting all-weather, around-the-clock intelligence gathering, will cost over $\$ 500$ million each, with a total system price tag as high as $\$ 12$ billion. Even the United States has balked at spending those sums for treaty verification and other monitoring. See Bunn, Spy Satellite Controversy Resolved, Arms Control Today, May 1989, at 23.

113. The budget for the United States On-Site Inspection Agency, the bureau established to implement the verification provisions of the INF Treaty, has grown to $\$ 50$ million for fiscal year 1990, with a staff of 223. See Morrison, Trusting, But Verifying, 21 Nat'l J. 2580, 2581 (1989).

In some other arms control situations, the costs of verification have undercut or altered the negotiations. In the talks aimed at producing an "Open Skies" agreement to permit unimpeded aerial reconnaissance, for example, Czechoslovakia has said that it would not have, and could not procure, the aircraft necessary to perform the permitted overflights, and Holland, Belgium, and Luxembourg have expressed the intention to pool their resources and conduct the inspection flights as a joint enterprise to save money. See Adams, Smaller Countries Hope to Reduce Open Skies' Cost, Data Limits, Def. News, Feb. 19, 1990, at 8.

114. In the chemical industry, for example, the United States, like most other countries, already requires private firms to maintain detailed accounts of all aspects of their operation and to file numerous reports related to pollution control, use of toxic substances, employee health and safety, and the like. See Carpenter, Government Regulation of Chemical Manufacturing in the USA as a Basis for Surveillance of Compliance with the Projected Chemical Weapons Convention, in 2 The Chemical Industry and the Projected Chemical Weapons Convention: Proceedings of a Stockholm International Peace Research lnstitute/Pugwash Conference (5 SIPRI Chemical \& Biological Warfare Studies) 11, 1I-24 (1986) [hereinafter Pugwash Conference]. These voluminous recordkeeping requirements would be greatly expanded under the verification standards of an arms control agreement.

Similarly in the nuclear power industry, the imposition of international safeguards to monitor the use of nuclear materials, equipment, and technology, in order to guard against possible diversion to weapons purposes, has proven expensive. Some plants have complained that they are placed at a competitive disadvantage compared to rivals who are able to operate without the incumbrance of treaty inspections. See D. Fischer, supra note 65 , at 21 . 
by treaties, such as the emerging CW convention, ${ }^{115}$ that touch heavily upon the activities of private industry: There is now a significant danger that foreign or international inspection could expose closely guarded trade secrets (such as production processes, customer lists, and patterns of consumption of raw materials) redounding, through an untraceable process of industrial espionage, to the competitive disadvantage of the inspected state. ${ }^{116}$

In sum, many states reasonably fear that if they join one of the important current or future arms control agreements, they will be politically, militarily, or financially disadvantaged in comparison with those who resist limitations upon armaments. ${ }^{117}$

2. Implementation. - Similarly, the implementation phase of modern arms control treaties seems almost as if it were contrived to push states away from the treaty's objectives, rather than strategically to promote them. Too many treaties have proven inadequate at instilling parties' confidence in the regime's power to monitor rivals' behavior, to investigate ambiguities, and to resolve doubts about compliance.

Verification of each party's fulfillment of its obligations is an essential aspect of arms control: no state is willing to restrain its own pursuit of self-defense options unless it is assured that potential antagonists are similarly shackled. ${ }^{118}$ Yet some multilateral arms control agreements have either ignored the subject altogether or dealt with it inade-

\section{See supra note 95 .}

116. The fear of exposing valuable trade secrets has been the single biggest concern that the American chemical industry has expressed about the new chemical weapons convention, and the negotiators have devoted considerable attention, as well as explicit provisions in the draft treaty text, to the problem of preserving confidentiality. Industrial rivalry has prompted fears that foreign inspections, ostensibly justified for purposes of arms control treaty verification, will actually be employed to pirate irreplaceable commercial confidences. See Carpenter, supra note 114, at 22-23; Hoffmann, Some Aspects of Verification from the Viewpoint of the Chemical Industry of the Federal Republic of Germany, in 2 Pugwash Conference, supra note 114, at 97, 97-104; The Spy in the Ointment for Negotiators, New Scientist, Jan. 14, 1989, at 27; see also Preliminary Structure of a Convention on Chemical Weapons, Annex on the Protection of Confidential Information, reprinted in Conference on Disarmament, supra note 91, app. I, at 77-82, (obligation to protect confidential information should prevent divulging anything but that necessary to implement convention).

117. The arms control process, to date, has not saved its parties much money; the treaties have not foreclosed many viable options that would have attracted substantial funding even in the absence of international restrictions. See International Disarmament Fund, supra note 71 , at 20 . The countries that have dominated the negotiationsprincipally the United States and the Soviet Union-have been motivated primarily by considerations of military security, rather than cost, and have not paid much attention to the possibility that disarmament could release funds for development purposes. See Sollie, supra note 76 , at 68 .

118. For example, several lingering questions regarding the Soviet Union's compliance with the obligations of multilateral and bilateral arms control agreements have proven to be highly controversial, with the United States government asserting that "[c]ompliance with arms control commitments remains an essential element" of arms control policy, and that violation "undermines the confidence essential to an effective 
quately. ${ }^{119}$ The implementation of these accords repeatedly has been troubled by the difficulty of assessing compliance: ${ }^{120}$ the procedures for gathering first-hand data about activities in the troubled locale have been too easily frustrated.121 Parties know that they can conveniently circumvent the purpose of the inspection, through subtle dilatory tactics or through incomplete support for the cooperative aspects of the verification measures, without necessarily violating the letter of the legal agreement, and that they can do so with relative impunity. ${ }^{122}$

3. Enforcement. - The most glaring shortcoming in existing arms control, as Phillip Trimble has noted, is the paucity of options available to an innocent state, or to the community of parties as a whole, when there is reliable evidence of a treaty violation. ${ }^{123}$ International law affords only an impoverished range of alternatives, none of which may be well suited to the particular provocation. Under the Vienna Convention on the Law of Treaties, ${ }^{124}$ an aggrieved state may terminate a

arms control process in the future." Soviet Noncompliance with Arms Control Agreements, President's Report to the Congress, Dec. 1988, at 3, 4.

119. The Geneva Protocol, supra note 23, the BWC, supra note 22, the Seabeds Arms Control Treaty, supra note 23, and the Environmental Modification Convention, supra note 23, all lack explicit, effective provisions regarding verification and enforcement.

120. Even the NPT inspection regime, which has been the most long-standing and widespread program of international verification, is far from satisfactory. The International Atomic Energy Agency (IAEA), which has responsibility for maintaining the safeguards and materials accountancy standards under a series of international agreements, has never been accorded the staffing and legal powers necessary to do a thorough job. States retain the powers, for example, to refuse to admit particular inspectors, to preclude samples being taken outside the country for analysis, and to decline to have new types of surveillance and monitoring equipment installed. Similarly, the IAEA has little power to conduct surprise or short-notice inspections. See D. Fischer, supra note 65, at 37-45; Goldblat, supra note 21, at 373.

121. Investigations into allegations of treaty noncompliance typically must confront both political and technical hurdles. In many instances the suspected state has been extremely reluctant to open itself to foreign scrutiny, and has inhibited the search for evidence. In addition, the physical proof of the use of banned weapons may be elusive and ephemeral, as indications of illegal activity (lingering chemical traces perhaps indicative of weapons usage, for example) decay relatively rapidly, or may be difficult to distinguish from naturally occurring agents. See Harris, Sverdlovsk and Yellow Rain, Int'l Security, Spring 1987, at 41, 44, 45, 79, 80, 87; Altman, Poison Gas Attacks: Why a Diaguosis Is So Difficult, N.Y. Times, Sept. 18, 1988, at 14, col. 3.

122. Cf. Dombey, supra note 87 , at 36 ("unless arrangements can be made quickly to strengthen these [nuclear nonproliferation] agreements and especially their monitoring and enforcement, then it may be too late to redress the situation in view of the increasing number of states who have or will shortly have access to nuclear weapon materials").

123. See Trimble, Beyond Verification: The Next Step in Arms Control, 102 Harv. L. Rev. 885, 889-91 (1989).

124. Vienna Convention on the Law of Treaties, May 23, 1969, 1155 U.N.T.S. 331 [hereinafter Vienna Convention]. The Vienna Convention is not in force for the United States, but the State Department has declared that most of the treaty's contents are nonetheless binding upon the United States as expressions of customary international 
treaty, or suspend its operation in whole or in part, upon a material breach of the obligations by another state ${ }^{125}$-but this use of negative sanctions would ordinarily lead to a dismantling of the treaty, rather than to the restoration of compliance, thus effectively ending the treaty regime that the innocent party presumably was endeavoring to sustain.

Other "remedies" available in international practice are similarly inept. A party may typically withdraw from an arms control regime when its "supreme national interests" have been jeopardized by developments related to the treaty, ${ }^{126}$ but that, too, does not help restore the status quo ante. A party may take other unilateral action, outside the treaty, to offset the putative advantages that the cheater has obtained, but this course can be expensive and time-consuming. ${ }^{127}$ The dispute may be taken to the United Nations, ${ }^{128}$ to various diplomatic

law. See Restatement (Third) of the Foreign Relations Law of the United States, Introductory Note to Part III: International Agreements at 144-45 (1986).

I25. See Vienna Convention, supra note 124, art. 60,1155 U.N.T.S. at 346 . A material breach is defined as an unwarranted repudiation of the treaty or "the violation of a provision essential to the accomplishment of the object or purpose of the treaty." Id. art. $60,93(\mathrm{~b}), 1155$ U.N.T.S. at 346 . The treaty has no provisions explicitly dealing with remedies for lesser types of breaches.

126. The ABM Treaty specifies that each party has, on six months' notice, "the right to withdraw from this Treaty if it decides that extraordinary events related to the subject matter of this Treaty have jeopardized its supreme interests." ABM Treaty, supra note 4 , art. XV, I 2, 23 U.S.T. at 3446, T.1.A.S. No. 7503, at 12. Similar language has been written into other arms control agreements. See SALT II Treaty, supra note 98, art. XIX.3, 18 I.L.M. at 1158; CFE Treaty, supra note 7, art. XIX, I 2, 30 I.L.M. at 22.

I27. For example, if one country believed that its treaty partner was deploying new combat aircraft in excess of the number permitted by treaty, it could elect to respond by building for itself additional antiaircraft radars and missiles, thereby preserving its own record of full treaty compliance, while still denying to the cheater the apparent advantages of the additional aircraft. These defensive procurements, however, would require additional time and money, and would not necessarily move the parties closer toward the type of military balance that the treaty originally contemplated. See Smith, Reagan Given Options on Soviet Radar Issue, Wash. Post, Nov. 18, 1988, at A34, col. 1 (when Soviet Union refused to dismantle illegal ABM radar at Krasnoyarsk, United States considered options such as reversing planned retirement of several aged Poseidon nuclear submarines).

128. In both the Environmental Modification Convention and the BWC, for example, parties undertake to consult with each other, including cooperating within the framework of the United Nations, to resolve treaty-related problems. Further, any state that believes that another party is violating the treaty is authorized to lodge a complaint with the Security Council. See Environmental Modification Convention, supra note 23, art. V, I 1, 3, 31 U.S.T. at 337, 338, T.I.A.S. No. 9614, at 5, 6, 1108 U.N.T.S. at 153, 154; BWC, supra note 22 , arts. V, VI, If 1,26 U.S.T. at 588, T.1.A.S. No. 8062, at 6, 1015 U.N.T.S. at 167. 
channels, ${ }^{129}$ to the court of world public opinion, ${ }^{130}$ or to existing international judicial or arbitral panels, ${ }^{131}$ but these have not often proven to be especially effective fora. Invoking economic sanctions or other international pressures has some attraction, but in many instances that process has proven to inflict more pain upon the state that imposes the controls than on the intended victim. ${ }^{132}$ The extreme option, military or covert force, is also unlikely in the long run to prevent the dispersion of new arms technology or the deployment of advanced weaponry. ${ }^{133}$

In short, the range of responses to a treaty violation is often too blunt or too ineffective: as a practical matter, the innocent state may have to choose between destroying the treaty regime in toto or acquiescing in the illegitimate behavior. ${ }^{134}$ Even when the world has been gen-

129. In addition to the usual ambassadorial channels that may be used to make demarches regarding treaty compliance issues, the United States and Soviet Union have established dedicated dispute-resolution bodies under some arms control agreements. These institutions are given mandates to discuss confidentially issues related to compliance and to exchange information related to performance of the treaty obligations. See ABM Treaty, supra note 4, art. X111, 23 U.S.T. at 3444-45, T.1.A.S. No. 7503, at 10-11; INF Treaty, supra note 93, art. XIII, 27 I.L.M. at 97.

130. The United States publicized its findings regarding the alleged use of "yellow rain" chemical weapons in Southeast Asia and Afghanistan by the Soviet Union and its allies during the early $1980 \mathrm{~s}$, in an attempt to marshall world public opinion against the Soviets. See Harris, supra note 121, at 57-62. Similarly, the United States has issued annual compliance reports describing in detail asserted Soviet violations of various arms control agreements. See U.S. Arms Control and Disarmament Agency, Soviet Noncompliance, ACDA Publication No. 120 (Mar. 1986).

131. The International Court of Justice could hear a case alleging treaty violation if the parties agreed to refer the case there. See Statute of the International Court of Justice, June 26, 1945, art. 36, I 2, 59 Stat. 1055, 1060, T.S. No. 993, at 30 . The ICJ, however, has not proven to be a very powerful body, especially in cases involving national security matters. See J. Sweeney, C. Oliver \& N. Leech, The International Legal System 44-69 (3d ed. 1988).

132. The post-World War II record of the imposition of economic sanctions includes frequent instances when attempts to influence the policies of other nations were ineffective, due to noncooperation or evasion by other states, as well as cases where sanctions backfired, inflicting greater losses on the domestic United States economy than on the target state. See B. Carter, International Economic Sanctions: Improving the Haphazard U.S. Legal Regime 10-31 (1988); Mufson, Sanctions Could Be TwoEdged Sword, Wash. Post, Aug. 4, 1990, at A17, col. 1.

133. In 1981, Israel launched a surprise air strike against nuclear installations near Baghdad that the Israelis feared would be used in support of an Iraqi nuclear weapons program. The attack destroyed the facility, causing a substantial delay in any Iraqi weapons development plans, but also provoked worldwide condemnation. See Council Condemns Israel's Air Attack on Iraqi Nuclear Reactor, 18 U.N. Chron., Aug. 1981, at 5, 5-6; S.C. Res. 487, 36 U.N. SCOR (2288th mtg.) at 10, U.N. Doc. S/RES/487 (1981).

The United States has considered the use of military force against the Libyan chemical weapons facility at Rabta but has not launched a strike that would destroy the facility or impede its functioning. See Feinstein, supra note 102, at 26.

134. In the long-rnnning dispute regarding the Soviet Union's construction of a radar facility near the Siberian city of Krasnoyarsk, for example, the Reagan Administration was persuaded that the installation was a violation of the ABM Treaty, see supra 
uinely convinced that illegal, shocking behavior has occurred-as with Iraq's use of chemical weapons in the Iran-Iraq War ${ }^{135}$-few countries have been able to find ways to bring effective leverage to bear. ${ }^{156}$

\section{National Calculations}

Overall, each state will do its own cost/benefit calculation, on an ongoing basis, about an arms control treaty, weighing the attractions and the disincentives in determining over time whether to sign, comply with, violate, or abrogate the accord. 137 International practice in recent years has revealed certain repeated patterns of state behavior in this area, and three groups of states generally may be identified. First, some states will be predisposed to join any significant arms control agreement, and they will exert political pressure on others to associate themselves with it, too. Although the attitudes of foreigners, even powerful and friendly foreigners, will not cause the leaders of any country to take unjustified risks with national security, world public relations can be a substantial factor influencing the thinking of most national leaders and the behavior of their states. ${ }^{138} \mathrm{~A}$ "bandwagon effect" may

note 4 , but found itself without an effective recourse. Repeated protests to Soviet offcials brought no satisfactory resolution, and internal reviews of American options were unable to identify any broader range of policy choices. Similarly, when the U.S.S.R. raised questions about the legality of certain American radar installations, the treaty did not offer suitable avenues for resolving the issue. Cf. Morrison, Radar Diplomacy, 19 Nat'l J. 17, 20 (1987) (describing ambiguity of treaty); Earle \& Rhinelander, The Krasnoyarsk Radar: A 'Material Breach' of the ABM Treaty?, Arms Control Today, Sept. 1988, at 9, 9-11 (even if United States were to declare radar a material breach of treaty, United States would acquire no additional rights or opportunities that would benefit national security in any way).

135. Iran had complained about Iraqi poison gas attacks since 1983; Iraq's denials were proven false by a United Nations investigation in 1984 , but the use of chemical weapons continued. See Urquhart, The United Nations and the Iraq-Iran War, 1988 SIPRI Y.B., supra note 20 , at $507,509-10$.

136. At the 1989 Paris conference on chemical weapons, the 140 nations represented agreed to condemn the use of chemical weapons, and to call for swift completion of a new treaty to ban them altogether, but the conference was unable to achieve consensus regarding any program of sanctions against the states that had employed chemicals in warfare, and most participants did not even mention Iraq and lran by name in discussing chemical weapons use. See Bunn, Paris Conference Condemns Chemical Weapons Use, Arms Control Today, Jan./Feb. 1989, at 27, 27.

137. See V. Utgoff, supra note 65 , at 2-8 (analyzing range of values that might prompt states to procure chemical weapons).

To simplify the presentation in this Article, we have adopted the conventional model of analyzing a government's behavior as if it were a unitary, rational actor. A more complex structure would probe the internal operations of this national entity, inquiring into the bureaucratic operating procedures, the personal stakes of key individuals, and other considerations, attempting to identify the diverse organizational and human pressures that affect national behavior. See G. Allison, Essence of Decision: Explaining the Cuban Missile Crisis (1971).

138. It is noteworthy, for example, that all the nonnuclear weapons states that are allied by treaty with the United States or the Soviet Union have either signed the NPT or 
thus induce many states to join new multilateral disarmament agreements even without additional incentives.

At the other end of the spectrum, for any particular agreement, there will probably be a group of countries whose leaders believe that adherence would not aid, and might significantly impair, national security. No legitimate inducement will prompt these countries to participate in the treaty regime; they are motivated principally by internal political factors or by perceptions of advantage and risk in their immediate geographical region. ${ }^{139}$

Between these two extremes there will be many nations whose participation in a particular arms control regime will be determined by a complex, ad hoc balancing of national interests and costs. For these states, joining the treaty would not seriously threaten national security; they may not even have tried to obtain the weapon system that is now being regnlated. But other things being equal, their leaders might prefer to keep their options open, the world being an uncertain and rapidly changing place, and the regional environment perhaps a dangerous one.

For the substantial group of countries in the latter category, the significant economic incentives that we propose could strongly reinforce the pressure of world public opinion. Cash and other valuable benefits on the barrelhead may prove to be especially attractive, making the value of joining the treaty concrete and immediate. As opposed to the more intangible considerations of "prestige" and retention of speculative future options, the immediate availability of significant development funds may make the difference between a country's adhering or not adhering to the next generation of multilateral arms control agreements. ${ }^{140}$

\section{The Link between Disarmament and Development}

The obvious bargain, then, is disarmament for development. ${ }^{141}$

otherwise accepted its safeguards on all their nuclear facilities. The major sponsors of a disarmament agreement have been able to exert substantial leverage upon their clients to adhere to the pact.

139. Even for these countries, the type of treaty regime we propose could make a difference in the long run. It would strengthen the hand of moderate factions, who could argue more persuasively in internal political councils in favor of joining the international consensus. If a moderate leader did emerge, he or she could sign a treaty, setting a course that would be difficult to reverse, even for any radical successors. Subsequent governments would have to abrogate or violate the agreement, losing economic benefits and risking sanctions, in order to add the controlled weapons to an arsenal.

140. Cf. Jones \& Müller, supra note 15, at 22 (advocating attempts to influence incentive structures of states most prone to proliferate by manipulating factors shaping their internal demands for new weaponry).

141. See Final Document, supra note 70, preamble \& I 2, at 372-73 ("Disarmament and development are two pillars on which enduring international peace and security can be built"); [1987] 12 U.N. Disarmament Y.B. 351, U.N.Sales No. E.88.IX.2 
But because this sort of tradeoff can succeed only if certain basic strategies are incorporated, this Part outlines seven principles that ought to guide treaty negotiators and implementors.

\section{A. Make the Development Funds Reliable}

For developing states to be enticed to accept this type of bargain, they will have to be confident that the pledges of economic assistance will not evaporate as soon as the ink is dry on the commitments to forego arms racing. To this end, the donor states should take steps to ensure that the promised assistance will be delivered reliably, independent of financial vicissitudes or political tempests.

'For this reason, to the extent that the assistance to be provided under a treaty consists of cash or fungible commodities, at least a few years' worth of assistance should be set aside in a dedicated international trust fund at the outset of the treaty, and periodically renewed as annual drawdowns occur. ${ }^{142}$ Disbursements should be made annually, and by an impartial international agency.

It is important to specify that the aid will be provided annually, rather than on a one-shot basis, so recipient states will learn to take it into account in their internal budgeting cycles every year, will come to depend upon it, and will notice very quickly the deleterious effects of its withdrawal or diminution. ${ }^{143}$

Similarly, it is surely preferable to funnel support of any kindwhether cash or technical assistance-through an international agency, established by the treaty and including membership by recipient states, rather than relying upon bilateral programs developed and conducted

(1987) ("Sweden declared that if the gap between . . . rich countries did not diminish, everybody's security ... would be threatened"); see also Deger, supra note 67, at 517 (if militarily advanced states are unwilling to agree to arms control because they fear that reductions might jeopardize their security, developing states are likely to follow their footsteps toward increasing weapons deployments, jeopardizing any hope of economic development).

142. In a comparable fashion, the Algiers accords, which resolved the United States/Iran hostage crisis in 1981, established a Claims Tribunal at the Hague through which a series of escrow accounts was established to compensate various categories of individuals, companies, banks, and governmental claimants. The agreement calls for Iran to replenish the security accounts whenever they fall below pre-established levels to ensure that the awards can be paid without delay. To date, the tribunal has awarded approximately $\$ 1.278$ billion to American nationals, and many more large claims are outstanding. See Update on U.S.-Iran Claims Settlement, State Dep't Fact Sheet, Aug. 9, 1989, reprinted in 89 Dep't St. Bull. No. 2152, Nov. 1989, at 60; see also International Disarmament Fund, supra note 7l, at 30 (describing procedures for initial endowment of international development fund, with continuous subsequent additions).

143. Cf. Beilenson, supra note 68 , at $842-43$ (surveying historical illustrations of foreign aid, including several in which lump-sum payments in advance failed to achieve their goals because recipients reneged on bargain after securing funds, as well as a few cases of installment-plan aid, which succeeded because recipients desired to continue flow of assistance). 
directly by donor nations. ${ }^{144}$ Disbursements should be made by the prearranged trustees, thereby placing the funds beyond the control of the donor states. The insulation provided by an agreed multilateral institution, which should grow over the years in credibility and respect, will also help to blunt some of the charges of economic imperialism or unwarranted intervention in domestic affairs that will inevitably arise. ${ }^{145}$ Individual bilateral aid programs can continue to exist, of course, but states may come to appreciate that by banding together they can accomplish more, and do so at less individual cost, than they could separately. ${ }^{146}$.

\section{B. Make the Linkage Explicit and Overt}

Much of the aura of impropriety that might otherwise surround this proposal would be dispelled simply by being open and aboveboard about the terms of the deal. Our program would have nothing to hide, and there would be no occasion for under-the-table personal selfenrichment for any officials. A detailed, published code of conduct that specifies what types of national behavior will earn specified degrees of international financial support is likely to be more influential, reliable, and respectable than the secret protocols or oral understandings associated with some past efforts at arms control. ${ }^{147}$

144. See International Disarmament Fund, supra note 71, at 27-29; Sollie, supra note 76 , at 78 .

145. Insisting upon a multilateral structure for the aid program also will help ensure that the sanctions portion of the regime is rigorously enforced: in a strictly bilateral relationship, the donor state might be too willing to "forgive" unfavorable bebavior, or might be tempted to elevate other foreign policy goals over nonproliferation. In contrast, the international regime might be more single-minded in insisting upon high standards of behavior regarding compliance with international norms. Cf. L. Spector, supra note 29, at 125-30 (Even though Pakistan's pursuit of nuclear weapons worried United States, generous aid programs continued in order to sustain Pakistan's participation in American efforts to assist Afghan rebels fighting Soviet forces.).

146. Cf. Pipart \& Sada, supra note 76, at 111-18 (advocating regional approach to disarmament and development). But see P.T. Bauer, supra note 72, at 63-64 (multilateral aid programs are worse than bilateral subsidies, aggravating economic inefficiencies).

147. Those understandings, of course, rarely remain covert, and their disclosure may create further obstacles. During the SALT I negotiations, for example, there were complaints from the United States Senate that Henry Kissinger's reliance upon private "backchannel" negotiations had resulted in "secret deals" with the Soviet Union that had been withheld from other segments of the American executive branch, as well as from the Congress. The process resulted in considerable political turmoil inside the United States, complicating the international negotiations, too. See T. Wolfe, The SALT Experience 88-89 (1979); see also R. Sivard, World Military and Social Expenditures 1987-88, at 11 (1987) (reporting exposure of several hitherto-secret international weapons-related agreements). The Case-Zablocki Act, 1 U.S.C. $\S 112 b(a)$ (1988), requires the President promptly to transmit to the Congress, or to designated committees thereof, the full text of every international agreement to which the United States becomes a party, even those that the executive believes ought to be kept secret from the general public. 


\section{Make the Tradeoff Proportional}

A new multilateral disarmament treaty should specify in detail what measures of development assistance, and what dollar volumes of support, are available for states that fulfill its requirements. Just as clearly, the treaty should spell out the debit side of the bargain: what kinds of misdeeds will result in the phased withdrawal of certain types and degrees of financial and other aid. The advantage of dealing with money, or with other economic incentives that can be measured in dollar terms, is that money is infinitely divisible, so the proffered financial incentives to join and comply with a future treaty arrangement can be related on a case-by-case basis to the particular circumstances.

The international body that implements the treaty should have the power to determine, prior to allocating each annual funding, whether a particular recipient state was in full compliance with all its treaty obligations and therefore authorized to receive its complete share of the funds. A party that had committed a minor or technical violation might be deemed, for that year, to be entitled to receive only ninety percent or ninety-five percent of its intended allocation. More egregious misbehavior would trigger greater reductions, pursuant to a calibrated, previously determined schedule of charges, or as developed over the years by an evolving case law of adjudications. The treaty would contain no obstacle, of course, to any recipient country's passing internal legislation that would give it a right to recover any lost share from a person or entity that had caused that state to violate its treaty obligations and consequently suffer a shortfall (e.g., a chemical manufacturing company that failed to file required production reports).

It will be important to develop a detailed code of conduct because there will be violations of future disarmament accords. As noted, the next generation of arms control treaties necessarily will become very technical and precise. This welter of specificity will be essential for the proper regulation of weaponry, but it also will occasion a high volume of reported inconsistencies and alarms. ${ }^{148}$ For example, declared stockpiles of chemicals or other substances will be discovered to be somewhat inaccurate, perhaps through unavoidable human error. Destruction schedules for excess arms will not always be scrupulously

148. In the context of strategic nuclear arms, the Standing Consultative Commission (SCC), created pursuant to the ABM Treaty, supra note 4, art. XIII, 23 U.S.T. at 3444 , T.I.A.S. No. 7503 , at 10 , has provided the vehicle for the United States and the Soviet Union to address and resolve confidentially many of the ambiguities and technical uncertainties that inevitably arise during the life of a complex and detailed arms control agreement. During much of its life, the SCC has been a busy and productive forum, with a great many small-but-important issues being raised by both sides. See Graybeal \& Krepon, SCC: Neglected Arms Control Tool, Bull. Atom. Scientists, Nov. 1985, at 30, 30- 31; Smith, Arms Agreement Breathes New Life into SCC, 229 Science 535, 535-37 (1985). 
met. ${ }^{149}$ Officials or nongovernmental personnel may, through no fault or bad will of the government, impede a required inspection. ${ }^{150}$ In areas in which the agreement is ambiguous, some states will deliberately engage in acts that are arguably innocent but that may eventually be judged to be violations. ${ }^{151}$

In addition, there may be more serious violations, such as refusal to comply fully with a mandatory "confidence-building measure,"152 incomplete cooperation with an on-site inspection, or nonparticipation in

149. Even the INF agreement, supra note 93, which has benefited from the most painstaking verification apparatus yet implemented, has suffered from occasional controversies regarding the schedules for dismantling excess weapons, the unanticipated deployment of SS-23s in Eastern Europe, and the Soviet Union's refusal to permit American observers at the Votkinsk missile plant to use X-ray machines to scan truck cargoes. See Lorenz, Controversies Mar Soviet INF Compliance, Arms Control Today, Apr. 1990, at 29, 29; Flournoy, Soviets Charge U.S. Missile Conversions May Violate INF Treaty, Arms Control Today, Mar. 1989, at 26, 26.

150. In on-site inspections conducted pursuant to the Stockholm Document, see infra note 152 , Soviet officials were initially aggressive, but later seemed to mellow toward the process; throughout they approached it with the attitude of reaching practical compromise solutions to the ambiguities and gaps in the agreement. See Stovall, The Stockholm Accord: On-Site Inspections in Eastern and Western Europe, in Arms Control Verification \& The New Role of On-Site Inspection 15, 28-30 (L. Dunn \& A. Gordon eds. 1990).

151. Sometimes, even in matters of intense national security, accidents happen and unintended violations occur. In the early years of the LTBT, supra note 20 , for example, the superpowers, with all their technological sophistication, occasionally vented radioactive debris from underground explosions, and sometimes the waste products escaped beyond national boundaries in violation of the agreement. See Pincus, U.S. Secretly Protested Radiation Leaks From Soviet Arms Tests, Perle Says, Wash. Post, May 9, 1986, at A23, col. 1 .

Similarly, regarding the Threshold Test Ban Treaty (Treaty on the Limitation of Underground Nuclear Weapon Tests), July 3, 1974, United States-U.S.S.R., art. I, 13 I.L.M. 906, 907 (signed but not ratified), which imposed a 150 kiloton ceiling on the yield of underground nuclear tests, the parties were aware that technical difficulties might mean that some explosions that were designed to produce yields very close to the maximum allowed size might accidentally exceed that level. They therefore agreed that one or two slight unintended breaches per year of the yield ceiling would not be considered a violation of the treaty, but would be a cause for concern and consultations. See Texts and Histories of Negotiations, supra note 19, at 185-86.

152. A "confidence-building measure" or "confidence- and security-building measure" (CBM or CSBM) is an agreement that does not actually reduce the two sides' arsenals of military equipment or personnel, but that enhances stability in other ways by making each side less worried that ambignous weapons-related activities occurring inside the other state might be a practice or preparation for an aggressive surprise attack. Examples of such measures include advance notification of large out-of-garrison maneuvers, permission for foreigners to conduct aerial surveys, exchanges of diplomatic briefings, and invitation of foreign observers to monitor troop movements. Several such measures were agreed upon in the Stockholm Document in 1986 and additional refinements are now under negotiation in the CDE talks in Vienna. See Document of the Stockholm Conference on Confidence- and Security-Building Measures and Disarmament in Europe Convened in Accordance with the Relevant Provisions of the Concluding Document of the Madrid Meeting of the Conference on Security and Co-operation in Europe, Sept. 19, 1986, reprinted in 1987 SIPRI Y.B., supra note 8, at 355, 355-69; 
an established dispute-resolution mechanism, that would warrant a more significant withholding of funding or the imposition of other sanctions, but still not justify the abrogation of the treaty. Even more egregious violations, such as deliberately tardy compliance with a schedule for dismantling of weapons or facilities, could also be dealt with in part by a previously announced menu of financial penalties. Moreover, in the cases of even the most outrageous conduct, such as illegal use of banned weapons in combat, the option of imposing meaningful immediate financial costs could provide an additional policy tool that offended states could bring to bear to help punish the violator, offset the advantages of cheating, and deter other potential miscreants. ${ }^{153}$

Like a system of civil or criminal fines, these treaty sanctions can be directly proportional to the seriousness or deliberateness of the violation, and they can deal more harshly with recidivists. These sanctions would, however, be less threatening than fines and less offensive to the country against which they are imposed: a fine can only be seen as punitive, in taking away something that is owned or possessed by the target, while our proposal simply declines to release to the target a quantity of funds to which it has a not-yet-vested claim. More importantly, unlike a system of fines-which, in the absence of an effective international police force, any charged state might simply refuse to pay-this sanction system would remain fully within the control of the international apparatus. If a violation is found, the annual monetary payments would be reduced or eliminated, and the erstwhile recipient could not unilaterally escape the treaty's reach.

\section{Make the Aid Specific and Useful for Economic Development}

The subsidy program should be designed to identify and target specific opportunities for enhancing economic development in each recipient state. The program should not rely exclusively upon cash transfers, ${ }^{154}$ but should emphasize a package approach, including capital, technology, management services, and marketing advice. ${ }^{155}$ Abdus Salam suggests that education grants and research support could also

Borawski, supra note 51, at 11-15; News and Negotiations, The Other European Negotiations: CDE Resumes Confidence-Building, Arms Control Today, Apr. 1989, at 24.

153. The negotiators will also have to develop suitable mechanisms for dealing with treaty violations committed by the donor states. Because withdrawal of financial privileges would not be applicable, other sanctions will have to be devised.

154. See J. Baker, supra note 73, at 1 ("Few of these countries [the Soviet Union and Eastern Europe] are interested in outright grants or aid. Instead, most are seeking what we call technical economic cooperation .....").

155. Cf. Sewell \& Contee, supra note 74, at 1023-24 (many middle-income developing states, such as Mexico, Taiwan, Venezuela, Brazil, and Nigeria, no longer need traditional concessional foreign aid, but will require nonconcessional financing to surmount debt problems and to support productive investment); J. Baker, supra note 73, at 6 (United States experts are providing advice to the Soviet Union regarding small busi- 
be useful attractions. ${ }^{156}$ Similarly, tariff concessions or guarantees to purchase (or to supply) particular goods at stable prices throughout the duration of the treaty could help. ${ }^{157}$ In-kind transfers of surplus equipment and materials could also play a valuable role in assisting local development efforts. ${ }^{158}$

Not all economic development is sound or sustainable, as P.T. Bauer has made clear; ${ }^{159}$ the international authority will have to search to identify productive opportunities and to minimize waste. ${ }^{160}$ Attention will have to be paid to both long-term and short-term opportunities and dislocations, and an individualized program of development will have to be crafted for each state. Each program will have to be monitored and reviewed critically to ensure effective performance and to avoid diversion or waste. ${ }^{161}$

Ideally, the development funds will be used to start new projects, to sustain experiments during crucial initial years, to create a modern infrastructure, and to open new sectors for ordinary indigenous commercial exploitation. In most instances, merely subsidizing the operating expenses of existing facilities and services would be less worthwhile. When recipient countries' governments so desire, the programs could be targeted to reach the poor directly, ${ }^{162}$ but even in these cases an emphasis should be given to training, investment, and opportunities for sustainable growth, rather than only to immediate relief. 163

ness operations, financial markets and stock exchange operations, efficient tax collection, and economic statistics).

156. See Salam, supra note 73 , at $8-10$; see also P. Harrison, supra note 70 , at 88 (small investment in spreading agricultural technology could dramatically increase farm productivity).

157. See P.T. Bauer, supra note 72, at 62 ; L. Reynolds, supra note 2 , at $60-64 ; A$ Programme for Survival, supra note 2, at 71, 145-46; Sewell \& Contee, supra note 74, at 1029.

158. Cf. International Disarmament Fund, supra note 71, at 24 (surpluses of equipment were widely distributed, to good effect, immediately after World War I1).

159. See P.T. Bauer, supra note 72, at 46 (arguing that foreign aid tends to bias recipient toward adoption of Western models of economic development, which may not be suitable in local context).

160. American aid programs during the 1950 s and 1960 s were often criticized for poor planning. An aide to Senator Patrick J. Leahy, chair of the Appropriations Subcommittee on Foreign Operations, recalls, "We built a lot of roads that went from nowhere to nowhere and power plant projects that turned out to cause huge environmental problems." Stanfield, supra note 75, at 1225; see also Fontanel, The International Disarmament Fund for Development, Disarmament, Spring 1986, at 19, 22 (discussing need to ensure that development assistance truly benefits recipients, not simply tying them economically to donor by creating captive markets for useless products).

161. See Pipart \& Sada, supra note 76, at 154.

162. See P.T. Bauer, supra note 72, at 49-50 (arguing that most aid programs serve to benefit the entrenched leadership in recipient states, rather than to improve the lives of the poor they were designed for).

163. See A Programme for Survival, supra note 2, at 94 (investment in irrigation systems, roads, rural electrification, fertilizers, and pesticides is better than food relief). 
A comparison with the NPT is illustrative here, for that treaty is the closest current analogue to what we propose, and the practical shortcomings of that set of exchange arrangements can guide future negotiators. Under the NPT-in addition to the basic ban on the further spread of nuclear weapons ${ }^{164}$-the parties undertook to share the thendazzling promise of civilian nuclear power. ${ }^{165}$ In particular, the nuclear "have" states promised in article IV of the Treaty to "cooperate in con-

164. In return for the promise, made by the states that did not then possess nuclear weapons, never to manufacture or otherwise acquire them, the NPT tradeoff elicited two basic commitments from the states that had already joined the "nuclear club." First, they agreed, in article VI, "to pursue negotiations in good faith on effective measures relating to cessation of the nuclear arms race at an early date and to nuclear disarmament, and on a treaty on general and complete disarmament under strict and effective international control." NPT, supra note 21 , art. VI, 21 U.S.T. at 490, T.I.A.S. No. 6839, at 8, 729 U.N.T.S. at 173. Second, they promised, in articles IV and V, to extend to other countries the non-military benefits of nuclear energy. Id., arts. IV, V, 21 U.S.T at 489-90, T.I.A.S. No. 6839, at 7-8, 729 U.N.T.S. at 172-73.

The failure of the major powers to conclude arms control agreements that satisfy the strict criteria of article VI has been a point of substantial contention at the various review conferences that have been convened to assess the operation of the NPT. Unless the superpowers register much better performance in this regard in the future- particularly on progress toward a comprehensive nuclear test ban treaty that would halt test explosions of nuclear weapons-even greater controversy is expected in the future. Again, the nonnuclear weapons states argue that under the NPT they have traded away a specific right (the option to develop their own nuclear arms) in return for only a vague, easily avoided promise to negotiate superpower arms control in the future. See $D$. Fischer, supra note 65, at 24-26; News and Comments, Sparring on Test Ban Likely at NPT Review, 229 Science 630 (1985); Goldblat, supra note 21, at 378-79.

165. The commitment to spread the benefits of civilian nuclear energy had two distinguishable components, both of which have suffered from adverse economics and simple neglect. Under article IV, the nuclear "have" states were supposed to share the anticipated growth of nuclear power generation, extending to the "have not" states the technology and materials necessary for civilian plants to replace fossil fuel and other facilities. See NPT, supra note 21 , art. IV, 21 U.S.T. at 489-90, T.I.A.S. No. 6839, at $7-8,729$ U.N.T.S. at 172-73. Under article V, the nuclear weapons states also promised to make available, on a nondiscriminatory basis and at as low a charge as possible, the potential benefits of "peaceful nuclear explosions" (PNEs). Id., art. V, 21 U.S.T. at 490, T.I.A.S. No. 6839, at 8, 729 U.N.T.S. at 173 . At the time the NPT was sigued, many people contemplated that nuclear explosions could be useful for diverse civil engineering projects, such as digging a canal, rerouting a river, clearing a navigation channel, or constructing an underground storage cavity. In fact, however, the dangers of PNEs came to overwhelm the advantages: the environmental harm was substantial, the economic costs turned out to be larger than anticipated, and the parties were unable to develop procedures for conducting PNEs that did not also enable the participants to obtain technological information that could contribute to the development of nuclear weapons. Accordingly, the United States' interest in conducting PNEs-or in making PNE services available to other states-quickly began to wane, and although the Soviet program lingered for a few more years, it, too, never achieved the prominence originally forecast. Again, the nonnuclear weapons states were left with little to show under article $\mathrm{V}$ for their adherence to the NPT; the nuclear weapons states avoided the promised sharing of technology and PNE benefits. See D. Fischer, supra note 65, at 23-24; Findlay, Peaceful Nuclear Explosions and the NPT: Letting a Dead Letter Lie, 10 Arms Control 219, passim (1989). 
tributing . . . to the further development of the applications of nuclear energy for peaceful purposes, especially in the territories of non-nuclear weapon States Parties to the Treaty, with due consideration for the needs of the developing areas of the world." 166

This language was widely understood at the time to be a part of an essential tradeoff, ensuring the nonnuclear states that, if they agreed to abandon any nuclear weapons aspirations, they would still share the anticipated bounty of emerging technology related to civilian nuclear power production. ${ }^{167}$ Within a few years after the treaty was negotiated, however, several Western states, particularly the United States, lost their ardor for nuclear power plants and became less interested in developing and promoting that form of energy. ${ }^{168}$ International nuclear commerce became less frequent, and the anticipated level of sharing the benefits of nuclear power has never been attained. ${ }^{169}$ Third

166. NPT, supra note 21 , art. IV.2, 21 U.S.T. at 489-90, T.1.A.S. No. 6839 , at 7-8, 729 U.N.T.S. at $172-73$.

167. See Maynes, UN Disarmament Efforts: Is There Life After the Second UN Special Session on Disarmament?, in Arms Control: The Multilateral Alternative, supra note 18, at 52, 57 (tradeoff was "basic bargain" that persuaded many nonnuclear weapons states to accept discriminatory standards of NPT).

168. When the NPT entered into force in 1970, orders for the construction of new nuclear power plants were pouring in, especially from the United States, but by 1975 , the demand had crested, and by 1985 , the nuclear power industry was in recession worldwide. Most recent estimates of the amount of power that will be generated in nuclear plants in the year 2000 are less than $20 \%$ of the estimates of a decade ago. See D. Fischer, supra note 65 , at 22.

169. In one important area, the NPT deals with the issue of costs in an entirely counterproductive fashion. That is, the treaty regime sensibly requires the imposition of "full scope safeguards" on the nuclear power activities of the nonnuclear weapons states, but does not mandate similar inspections and controls on the comparahle activities of the nations which were already acknowledged to possess nuclear weapons. The rationale for this distinction was that the controls were desigued to deter covert diversion of nuclear materials from civilian to military applications, and that no such diversion would be logical in states that were permitted by the treaty to maintain independent, unsafeguarded nuclear military facilities.

Some states were initially concerned that the inspection scheme would inflict excessive coists on the developing states, placing them at a competitive disadvantage vis-à-vis the nuclear weapon states, who could avoid those expenses and burdens in their own generation of civil nuclear power. In response, each of the nuclear weapons states has made a "voluntary offer," allowing the application of comparable international safeguards on some or all of its civilian nuclear facilities (while still retaining the privacy of its military programs). The concept was that these voluntary programs would help demonstrate to all states that the safeguards programs were not too costly or unfair. See [1988] 13 U.N. Disarmament Y.B. 260, U.N. Sales No. E.89.IX.5 (1988); Texts and Histories of the Negotiations, supra note 19, at 223-60; D. Fischer, supra note 65, at 18.

A more sensible system, however, comparable to the one we propose in this Article, would call upon the nuclear weapons states to compensate the nonnuclear weapons states for the price of the inspection system. Instead of compounding the costs of verification by making every state bear an equal burden, even when there is no arms control rationale for imposing the safeguards on a particular country, it would be more efficient to require safeguards only where they are necessary to ensure compliance with the treaty, and to 
world expectations that they had traded their right to build nuclear weapons in exchange for atomic development assistance have therefore been profoundly disappointed. ${ }^{170}$ Oswaldo De Rivero, the president of the 1990 NPT review conference, accordingly highlighted the need to redress this imbalance by elaborating the existing treaty regime in a way that provides additional economic incentives, tied to the needs of individual developing states, to make the treaty more attractive to nonparties. ${ }^{171}$

The problem with article IV of the NPT from the perspective of developing countries is not that it embodied a trade-off, but that the treaty was written in the most general terms, with no concrete commitments from the developed world. The negotiators were too timid, failing to reach the degree of specificity that could have converted hortatory language into a legally enforceable instrument. We suspect that the history of article IV would have been quite different if, for example, the developed countries had explicitly undertaken to build, within the first ten years of the treaty regime, at least one nuclear power plant in each developing country that adhered to the agreement. ${ }^{172}$

treat the costs of those safeguards as a part of the price of the overall treaty regime, to be borne or redistributed in some other fashion. If the wealthy states would pay for all safeguards everywhere, they would thereby help encourage developing countries to join the treaty, and would not create additional, unnecessary costs for their own nuclear power activities.

170. The International Atomic Energy Agency has projected that by the end of the century, nuclear power will account for $30 \%$ of the electricity generated in the developed countries, but only $7 \%$ of the electricity generated in the developing states, with half or more of the developing countries' total being confined to just two states, Taiwan and Korea. See D. Fischer, supra note 65, at 11.

The developed states' failure to make nuclear power more widely and cheaply available is likely to be a substantial issue at future NPT review conferences, including the 1995 conference that will decide whether to extend the treaty beyond its initial 25-year term. See Dunn, supra note 54, at 100-01; Mayorsky, supra note 54, at 89 .

171. See De Rivero, NonProliferation: A Key Element of a Planetary Culture and Common Security for the Twenty First Century, Keynote Address to the Conference on Non-Proliferation, Guernsey, May 11-14, 1990, at 8-9 (on file wirh Columbia Law Review). The president also noted that many developing countries "obtain nothing from the treaty" and continue to adhere to it mainly out of a sense of legal inertia. Id.

172. Making this type of explicit trade would not preclude the parties from changing their minds and agreeing to alter the bargain if subsequent economic or environmental concerns made the initial promise of a nuclear power facility less attractive than originally contemplated. When changed conditions emerge, the parties could renegotiate the treaty, substituting some other form of compensation for the facility that one or both sides had come to consider undesirable. But the explicit contractual tradeoff (and the requirement that developing states consent before the treaty is modified) would avoid putting the nonnuclear weapons states in the unenviable position in which they currently find themselves under the NPT, having foresworn an important weapons capability and receiving nothing tangible in return. 


\section{E. Tie the Substance of the Development Programs to the Substance of the Disarmament Programs}

Whenever possible, there should be a clear technical and economic relationship between the type of assistance being provided and the military options being foresworn. This form of linkage can make the bargain more politically palatable for donors and recipients alike, emphasizing the equality of the parties that will be essential for future disarmament agreements.

For example, it may be easier for many countries to accept fund: earmarked as "construction grants" for the creation of a new chemical or fertilizer factory in exchange for commitments not to produce chemical weapons. ${ }^{173}$ Indeed, in March 1990, Moammar Gadhafi actually suggested that Libya would abandon its suspected chemical weapons facility at Rabta in exchange for Western construction of a modern pharmaceutical factory. ${ }^{174}$ The alternative, offering unrestricted cash for the same type of obligation, gives the recipient greater freedom regarding the ultimate use of the funds, but may be more offensive or politically unsound for both sides.

Not every disarmament provision will lend itself to this type of linkage, but with creativity and commercial incentives, a suitable association could usually be found: trading satellite technology for restrictions on antisatellite weaponry; trading fisheries supports for limitations on attack submarines; and so on. ${ }^{175}$

It similarly may be useful to characterize at least some of the economic subsidies as "retooling assistance," to help cover the anticipated costs of converting plants and equipment from weapons production to civilian applications and of retraining the labor pool. 176 Another portion of the aid could be denominated as "reimbursement" for the bur-

173. Whenever the facilities provided under the agreement could be adapted to military uses (e.g., a chemical factory that could be converted to manufacture nerve gas) the facilities should be subject to monitoring and inspections by the international agency established under the agreement.

174. This arrangement was said to provide a solution to the international concern about Rabta and still allow Libya to save face. See Parmelee, Libya Said to Offer to Dismantle Plant If lt Is Given New One, Wash. Post, May 3, 1990, at A33, col. 2.

175. In some circumstances, it might be useful to link development and disarmament across more than one treaty simultaneously. That is, state $X$ might be reluctant to adhere to a new treaty limiting its arsenal of chemical weapons as long as it fears that its neighboring state $Y$ is retaining a stockpile of nuclear arms. At the same time, $Y$ may have no interest in developing chemical weapons itself, but would not dismantle its nuclear forces as long as $X$ retains chemical weapons capabilities. A single package that addresses all these concerns at once-and that throws in important assistance to promote economic growth in both states-may be the only procedure for breaking the impasse.

176. See Dumas, Economic Conversion: Preparing for Peace, Disarmament, Issue 2, 1990, at 197, 205-07; Adams, Economic Conversion Misses the Point, Bull. Atom. Scientists, Feb. 1986, at 24, 24; see also IA I. Thorsson, In Pursuit of Disarmament: Conversion from Military to Civil Production in Sweden 271-98 (1984) (studying in de- 
dens imposed by the verification inspections and for the risks, however small, that some of the inspectors might engage in untoward industrial espionage. Education grants or research support might serve a similar function. ${ }^{177}$

\section{F. Include an Obligation to Participate in Treaty Verification and Enforcement Systems}

To avoid some of the worst shortcomings of existing arms control agreements, future treaties should specify that each recipient's share of the annual development funds will also depend upon its punctilious observation of the implementation process. ${ }^{178}$ That is, each state must not only comply with the substantive disarmament provisions, it must also compile a clean record of respect for, and cooperation with, the associated verification and enforcement systems. ${ }^{179}$

Thus, a state could lose a portion of its share of benefits by failing to submit all the required disclosures about weapons production and destruction, by impeding the functions of automated monitoring equipment, by frustrating the activities of on-site inspectors, by failing to participate in whatever dispute-resolution procedure the treaty establishes, or by thwarting international efforts to effectuate a series of sanctions against treaty violators.

Each future disarmament treaty should specify an international mechanism for clarifying ambiguities regarding compliance, and should identify an authoritative institution for registering final adjudications. ${ }^{180}$ There need not be a separate fact-finding and adjudicating

tail the possibility of converting national economy to lower levels of military spending pursuant to future arms control agreements).

177. In some states, the military serves both as an employer of last resort and as a forum for providing basic training in literacy, health care, technical skills, and organization. See L. Reynolds, supra note 2, at I04. If the aid program we envisage could provide suitable alternative mechanisms for fulfilling these important social functions, it might be easier for a developing country to reduce the size of its army. See Palme Commission Report, supra note 47, at 91-93 (in most developing states, military spending typically does little to promote employment for those who need it most).

178. Both the BWC and the Environmental Modification Convention contain obligations upon the parties "to cooperate in carrying out any investigation which the Security Council may initiate" in response to allegations of noncompliance. BWC, supra note 22, art. VI.2, 26 U.S.T. at 588, T.I.A.S. No. 8062, at 6, 1015 U.N.T.S. at 167; Environmental Modification Convention, supra note 23, art. V.4, 31 U.S.T. at 338, T.I.A.S. No. 9614 , at 6,1108 U.N.T.S. at 154 .

179. Cf. Lowenthal \& Wit, The Politics of Verification, in Verification and Arms Control, supra note 98 , at $153,162-65$ (treaty verification has become intensely political issue, with uncertainties in monitoring process and lack of consensus about appropriate standards undercutting progress toward arms control).

180. The International Court of Justice is one possible forum for this dispute resolution, and there have been suggestions that several countries are interested in the possibility of making the court a more important center of international judicial activity. See Cody, Soviet, U.S. Proposals Animate World Court, Wash. Post, Nov. 24, 1988, at Fl, col. 5. In addition, the United Nations Secretary General has recently created a trust 
organization for each disarmament treaty; several could efficiently be folded into the same umbrella organization. ${ }^{181}$ But whether there is one such institution or many, each treaty must insist that good faith, comprehensive implementation of its decisions is required for full receipt of the promised economic aid.

\section{G. Design an Equitable, Acceptable Mechanism for Collecting and Distributing the Financial Aid}

Developing the practical mechanics for a system of positive economic incentives is more difficult than constructing the theoretical case in its favor. Important and sensitive problems abound regarding the overall size of the monetary transfers, the division of responsibilities among the paying states, and the relative shares to be made available to potentially eligible countries.

These questions have no "right answers," but a few useful guidelines may be discerned. First, the total amount of funds available for all the disarmament treaties should bear some logical relationship to the quantity of resources to be freed up as a "peace dividend" generated by the ending of the Cold War. ${ }^{182}$ Many leading experts now estimate that the United States could prudently reduce its defense budget by at least $\$ 150$ billion per year (compared with what annual defense expenditures would have been if the Cold War had continued) and still meet its military commitments and protect its interests in the planet's reconfigured political environment. ${ }^{183}$ If we double that figure to represent

fund "to make available financial assistance to States where necessary so as to enable them to use the Court for the settlement of their legal differences." United Nations: Secretary-General's Trust Fund to Assist States in the Settlement of Disputes Through the International Court of Justice, 28 I.L.M. 1589, I589 (I989).

181. Cf. Trimble, supra note 123 , at 905 (proposing single Institute to perform fact-finding and dispute-resolution functions for all modern arms control agreements).

182. Political considerations make it highly unlikely that a substantial program of development assistance could be reliably funded through tax increases, deficit spending, or reduced domestic consumption. As a result, reduced defense spending via multilateral arms control offers the surest method for freeing up necessary monies. See Klein, Disarmament and Socio-Economic Development, Disarmament, Spring 1986, at 49, 56; see also Disarmament and Development, supra note 73, at 140, 147-49 (assessing prospects for tying development assistance to "disarmament dividend").

183. See $\$ 150$ Billion a Year: Where to Find It, N.Y. Times, Mar. 8, 1990, at A24, col. 1 (editorial pt. 1); $\$ 150$ Billion a Year: How to Spend 1t, N.Y. Times, Mar. 9, 1990, at A34, col. 1 (editorial pt. 2); cf. Defense Budget Task Force of the Committee for National Security and the Defense Budget Project, Restructuring the US Military: Defense Needs in the 21st Century 7-10 (1990) (projecting possible cuts of approximately $\$ 150$ billion per year by 2000 ) (on file with Columbia law Review).

Although the massive United States response to Iraq's invasion of Kuwait has led some analysts to question whether there will in fact be a significant cut in American armed forces and a resulting "peace dividend," several months into the Desert Shield operation, the Navy's top program planner spoke of the Gulf buildup as "just a perturbation in the flow of events" that would not fundamentally alter future downward budgetary trends; other military and political leaders were also planning to continue to 
the savings for the entire developed world, and assume that domestic needs will have priority claims on ninety percent of the total savings in each country, ${ }^{184}$ then approximately $\$ 30$ billion per year should be available for transfer to other countries to meet new international security needs. If half a dozen important new multilateral disarmament treaties must be negotiated, or existing treaties enhanced, over the next two decades, then the incentive structure for each could involve transfers on the order of $\$ 5$ billion per year. A substantial portion of this sum would come in the form of noncash technical assistance and import subsidies, but the sheer dollar volume alone is impressive, and could make a major impact. ${ }^{185}$

As a second necessary mechanism to implement this proposal, the treaties must establish some objective basis for determining which countries, by virtue of their relative wealth, would be required to be donors, which ones would be eligible to be recipients, and which ones would be neither donors nor recipients. Various types of criteria could be adapted for drawing these lines. ${ }^{186}$ For example, each treaty party whose annual United Nations dues amounted to more than one percent of the UN's total budget might be required to contribute to the development fund, according to each state's particular ability to pay. ${ }^{187} \mathrm{Sim}$ -

reduce the overall size of United States armed forces. See Gulf Crisis Poses Dilemma for U.S. Military Facing Cutbacks, Wash. Post, Dec. 23, 1990, at Al, col. 2. Even in the midst of the Desert Storm fighting, American defense officials were preparing reduced future military budgets, extending the downward trend in defense spending. See Amid War, Pentagon Proposes Cuts, Wash. Post, Feb. 2, 1991, at A4, col. 1; Morrison, Schizophrenic Budget, 23 Nat'l J. 326, 326-30 (1991).

184. Cf. IA I. Thorsson, supra note 176, at 316 (assuming that Sweden could devote to augmented international development efforts approximately $10 \%$ of savings it might realize from reduced military budgeting pursuant to future disarmament treaties).

185. Some have expressed reservations about linking development with disarmament too rigidly on the grounds that each issue ought to be pursued as vigorously as possible without either one being held up by difficulties in the other, and that the needs for development assistance are, at least in the short run, much greater than the amount of funds that could reasonably be released by foreseeable arms control measures. See Final Document, supra note 70, ๆ 8, at 373; [1987] 12 U.N. Disarmament Y.B. 350, U.N. Sales No. E.88.1X.2 (1987) (summarizing statement of France).

186. Some earlier studies have proposed that donations of development aid could be based upon the size of each donor's military budget or on the volume of its international arms transfers. See Disarmament and Development, supra note 73, at 144-47; Fontanel, supra note 160, at 23 . We prefer a program based strictly upon each state's financial ability to pay, which more accurately takes into account the situation of states, such as Japan, that have affuent economies and low levels of military activity.

187. The General Assembly establishes the scale of assessments for the apportionment of the expenses of the organization, and in 1990 the following member states each were assessed greater than one percent of the total budget: Australia (1.57\%), Belgium (1.17\%), Brazil (1.45\%), Canada (3.09\%), France $(6.25 \%)$, German Democratic Republic $(1.28 \%)$, Federal Republic of Germany (8.08\%), 1taly (3.99\%), Japan (11.38\%), Netherlands (1.65\%), Saudi Arabia (1.02\%), Spain (1.95\%), Sweden (1.21\%), Ukraine $(1.25 \%)$, Soviet Union (9.99\%), United Kingdom (4.86\%), and United States $(25.00 \%)$. G.A. Res. 223, 43 U.N. GAOR Supp. (No. 49), U.N. Doc. A/43/49 (1989). There are 
ilarly, each party whose per capita income or per capita gross national product ranked among the poorest sixty percent of the world could be eligible to become a recipient. ${ }^{188}$ Parties whose financial position fell between these extremes could elect to become donors but not recipients. The United States, Japan, and Western Europe would therefore be the principal donors for the foreseeable future; they should collaborate among themselves-driven by the fear of a rapidly arming worldto ensure that the cost burden is equitably shared among all the leading developed states.

Other difficult questions involve apportioning the available annual funds among the recipients. Although no method is perfect, we favor an allocation system designed to focus on the economic need of each particular recipient, as influenced by both its population and its per capita income or wealth. ${ }^{189}$

While the mechanics of such a scheme may be complicated, it still seems superior to other possible allocation algorithms. For example, the idea of providing an equal share of the funds to each recipient party that is in compliance with its treaty obligations would have the advan-

some anomalies on this list, but it provides a good starting point for developing a list of states that should contribute to the development fund. See also International Disarmament Fund, supra note 71, at 18 (describing various proposals for heavily armed and economically advanced states to provide most of support for international development programs).

188. Statistics provided by the World Bank list 42 countries as "low income economies," with per capita gross national product less than $\$ 500$. Another 35 countries are considered "lower middle income," with per capita gross national product between $\$ 500$ and $\$ 2000$. These two categories embrace $64 \%$ of the 120 reporting countries, and a comparable percentage of the world's population. See International Bank for Reconstruction and Development/The World Bank, World Development Report 1989, at 164-65 (1989). Again, there are a few surprises, but the ranking system provides a viable starting point for allocating the payments. See A Programme for Survival, supra note 2, at 78 (focusing on 29 poorest countries, concentrated in two "poverty belts"). But see P.T. Bauer, supra note 72, at 53-54 (arguing that it is misleading to compare income levels across different states).

189. In principle, the allocation formula could also take into account a recipient's ability, and its prior record, at making productive use of international development funds, and could also accord preferences to states that had particularly compelling local programs. This feature could help reduce waste and inefficiency, ensuring that the development purposes of the overall program were being realized. At the same time, any formula that relied upon someone's judgment about whether the development funds were being properly utilized might become so political and controversial that it would detract from the program's arms control purposes.

Each developing state will have its own needs and resources, and a unique package of assistance should be fashioned for each. On the other hand, some needs are likely to be quite similar from country to country, and in many instances a regional approach to the problems may offer greater opportunities. See D. Fischer, supra note 65, at 11; see also International Disarmament Fund, supra note 71, at 25-26 (suggesting criteria for setting priorities among recipient states); Disarmament and Development, supra note 73, at 151 (considering which states should be prime beneficiaries of international development fund). 
tage of the greatest simplicity, but it seems arbitrary: it does not focus on either the problem of disarmament or the needs for development. An alternative, allocating a greater proportion of funds to those nations that pose the greatest potential military danger, such as those deemed most likely to "hold out" against the treaty and deploy the destabilizing weapons, would be even worse. Such a system might have a surface plausibility, in targeting the incentive scheme directly to deter the most provocative countries. But that approach would become counterproductive in the long run by instituting a perverse incentive to "build up to build down": a state could increase its share of the multilateral funds by cynically teetering on the brink of making the prohibited deployment.

It might be possible for the treaty document to avoid specifying any allocation criteria at all, leaving it to the parties, in unbounded periodic bargaining over the implementation of the agreement, to specify via a political process the percentage of funds that would be allocated to each eligible recipient. This system, however, would have the flaws of both the plans discussed above: it would be perceived as arbitrary and chaotic, ${ }^{190}$ and it would encourage a feigned interest in acquiring the advanced military technology as a bargaining chip.

Among the simpler allocation systems, therefore, the best plan would be to apportion the available funds according to the poverty and population of the recipient countries. No system can perfectly reflect the relative needs of all countries, but it should be feasible to approximate a fair and rational basis of distribution. Under this plan, to be sure, many countries that lack the desire or the capability to produce the banned weapons would nonetheless collect the development funds and thereby get a "free ride" on the developed countries' disarmament concerns. But to the extent that the system is at least in part a true international economic aid program providing the additional benefit of preventing new arms races, this "unearned" benefit should be of relatively little concern, particularly since we must appreciate that in the

190. Multilateral arms control negotiations, conducted through the United Nations or elsewhere, tend to be marked by rhetoric and procedural wrangling, but they sometimes have been effective nonetheless. See Maynes, supra note 167, at 52-72; Luck, A Future for Multilateral Arms Control, in Arms Control: The Multilateral Alternative, supra note 18 , at 213,218 . To earn the respect-and the continued support-of the donor states, the disarmament organizations will have to find a way to avoid becoming encumbered by the bureaucracy and divisiveness that have sometimes characterized other multilateral organizations. See International Disarmament Fund, supra note 7I, at 27. In some instances, perceptions of extraneous politicization, hostility toward Western values, and irresponsible budgeting have led to important defections, such as the United States' 1984 withdrawal from the United Nations Educational, Scientific and Cultural Organization. See Newell, Perspectives on the U.S. Withdrawal from UNESCO, Address by Assistant Secretary of State, Oct. 31, 1984, reprinted as Dep't of State Current Policy No. 634; cf. P.T. Bauer, supra note 72, at 66-68 (multilateral organizations are wasteful, inefficient, and politically biased). 
long run, countries develop, technology spreads, and governments change, so any country may pose potential security problems.

\section{Objections to the Proposal}

A radical suggestion such as ours is bound to stimulate a variety of objections. In this Part, we attempt to deal with four of the most powerful counterarguments against the program outlined above.

\section{A. Morality}

Some will no doubt complain that it is improper to "bribe" other states in this way, that injecting cash or conditioned in-kind benefits so overtly into the statecraft of sovereign nations impermissibly cheapens the vaunted traditions of international relations. In the same vein, some will resent this type of application of economic leverage, considering it to be just as aggressive and improper as a direct application of coercive military power. ${ }^{191}$

We look upon these transactions as business propositions, however, and we see a world of difference between a personal, under-thetable emolument to a nation's leader and a program of financial aid that is overt, dedicated to a high public purpose, and freely agreed upon among independent states. "Immorality" is not inherent in all unconventional arrangements between willing sellers and willing buyers, and both groups of participating states here would be seeking symbiotically to promote national and global interests.

From the point of view of the developed states, the acute future military threats to peace and security will increasingly originate in developing countries that deploy advanced weapons systems. It is surely legitimate for the developed societies to anticipate this emerging danger and to attempt to protect themselves from it. If persuasion and ordinary military means of self-defense are insufficient, it is "moral"indeed, it is the only responsible course of action-to attempt to bring other assets into play. When the developed states can "buy" national security at a much lower price than in the past, by shipping aid and assistance to wavering countries and providing those recipients with additional incentives to persuade them to foreswear pursuit of new destabilizing weaponry, then the international community ought to applaud the creativity and nonviolence of the new approach.

From the point of view of the developing states, as "sellers" of disarmament, a bargain along these lines would be unattractive at any price if it genuinely reduced their safety or autonomy. But there is no inherent reason why an increase in the security of the developed nations should decrease the security of other countries. Most threats to third world countries are posed not by the developed world but by 
other third world countries; ${ }^{192}$ for many states, therefore, verifiable multilateral arms control agreements with economic incentives added will be militarily as well as financially advantageous. Indeed, because regional instability often feeds on the fear that rival states might obtain new nuclear, chemical, or other advanced arms, the opportunity to curb or prevent future arms races in high-technology weapons is of the utmost importance to developing states. ${ }^{193}$ If those apprehensions can be reliably put aside through verifiable arms limitation agreements-a strategy that has achieved some successes, ${ }^{194}$ but one that, in the absence of sufficiently attractive economic development incentives has not yet been widely adapted-then the developing states should be freer to turn their attention away from defense and toward urgent domestic needs. ${ }^{195}$

There is, to be sure, a lingering distaste for giving and accepting handouts, ${ }^{196}$ and any charity that is linked to a required response is perhaps less generous than an unrestricted donation. But the fact remains that string-free subsidies have not been forthcoming from the developed states, and the best recourse at this time for the developing states to achieve the levels of foreign support that they so desperately need is to connect this support with the self-interest of the donors.

Our concept could thus unite the several countries of the world in mutually advantageous multilateral disarmament at the same time that it reinforces their shared progress toward economic betterment. While some may hesitate to reduce the perquisites of national sovereignty to crass dollar terms, we consider a frank recognition of the relationshipand a concrete effort to deal productively with the needs of all statesthe most morally responsible approach to effective management of the problems of the twenty-first century.

192. See Pipart \& Sada, supra note 76, at 102; Wilson \& Wallensteen, supra note 57 , at $285-98$.

193. See D. Fischer, supra note 65, at 13, 30-36.

194. See, e.g., Treaty of Tlatelolco, supra note 23 (providing nonnuclear regime for entirety of Latin America).

195. Cf. Disarmament and Development, supra note 73, at 90 (developing states will have to rechannel domestic spending away from military purposes to promote economic growth); Palme Commission Report, supra note 47, at 91 (concluding that military spending, in developing states as well as in developed economies, reduces economic growth by usurping resources that would otherwise be available for domestic investment); Klare, supra note 13, at 8-12 (analyzing regional and domestic political pressures that lead to counterproductive arms races among developing states).

196. Despite the relatively low political popularity of foreign assistance legislation, opinion polls reveal that a majority of Americans favors providing foreign aid, and private American charitable donations reveal a deep internationalist humanitarian spirit, caring about poverty abroad as much as about poverty at home. On a per capita basis, individual American donations for overseas relief and development are "among the highest in the world." Sewell \& Contee, supra note 74, at 1020. 


\section{B. Political Acceptability}

Our proposal will have to surmount diverse political attacks from many quarters. In some recipient countries, leaders will be accused of selling out their nations' patrimonial independence for a mess of pottage. In some paying countries, leaders could be criticized for wasting national revenues to pay other states to do what they should and would do anyway. In some countries that would be neither payers nor recipients, there might be complaints that poorer states were being unfairly advantaged.

The steps that have already been outlined should help to make the proposal more politically tolerable. But the critical issue remains the plausibility of attempting to cut a mutually beneficial deal: those (in either the developed or the developing states) who believe that "we should not be doing business with those people" will never be tolerant of our approach. ${ }^{197}$ For some, the regimes in other parts of the world are so hateful and repugnant that it is inconceivable that areas of shared interests could or should be identified and exploited. ${ }^{198} \mathrm{We}$, obviously, have come to the opposite conclusion: despite the enormous social, political, economic, racial, and cultural differences between states, they have some concerns in common; thus, a balanced set of tradeoffs may enable everyone to emerge a winner. The ultimate response, then, to the question of political acceptability will itself be a political measurement: if the program works-if it achieves its purposes of arms control and economic growth for the developed and for the developing states-then it will be a political success, too. ${ }^{199}$

In the context of political tolerability, it is also worth contrasting the program that we advocate here with the previous, more general international efforts, sponsored by the United Nations and other groups, to link disarmament and development. ${ }^{200}$ Both arms control and im-

197. Accepting the type of deal we propose does not require the states to overlook or downplay their other outstanding antagonisms. The United States will be able to continue to oppose repressive, hostile regimes around the world, and to resist and undermine outlaw states and rogue leaders through a variety of policy devices. Our approach, however, recognizes that along with these profound differences, we can identify certain areas of shared interests, and that we should be able to find ways to pursue the mutual goals at the same time that we maintain our adversary dealings in other contexts. Thus, there is no necessary linkage between progress on the problems of development and disarmament and progress on the host of other international issues, such as territorial disputes or human rights concerns.

198. See, e.g., P.T. Bauer, supra note 72, at $42-43$ (criticizing West for providing aid to radical regimes, as creating "a collective rod for its own chastisement").

199. Cf. A Programme for Survival, supra note 2, at 27-28 (after surveying leading states, commission concludes there is sufficient political will to address problems of development seriously).

200. The United Nations and other groups have underscored, since at least 1950 , the political and economic association between development and disarmament, and numerous studies and resolutions have advocated reduced military expenditures coupled with increased resource transfers to the developing world. See Deger, supra note 67, at 
proved living standards are principal goals articulated in the United Nations Charter, 201 and the General Assembly has for a generation sponsored a series of resolutions ${ }^{202}$ and investigations ${ }^{203}$ that have unanimously concluded that the problems are inextricably linked: "The world can either continue to pursue the arms race with characteristic vigor or move consciously and with deliberate speed toward a more stable and balanced social and economic development within a more sustainable international economic and political order. 1t cannot do both."204 The global community, therefore, has repeatedly called upon the advanced economies, and especially upon the superpowers, to restrain their military spending and dedicate the newfound bounty as additional aid to the poor. ${ }^{205}$

Nevertheless, the developed states have remained largely unresponsive to these pleas; as Jurgen Brauer has noted, the argument linking development and disarmament seems to have lost political

521-23; [1987] 12 U.N. Disarmament Y.B. 339-44, U.N. Sales No. E.88.1X.2 (1987); U.N. Inst. for Disarmament Research, Repertory of Disarmament Research 71 (1982) [hereinafter Repertory of Disarmament Research]; Disarmament and Development, supra note 73 , at $136-40$.

201. The preamble to the United Nations Charter notes the states' determination "to save succeeding generations from the scourge of war," "to promote social progress and better standards of life," "to practise tolerance and live together in peace," and "to employ international machinery for the promotion of the economic and social advancement of all peoples." U.N. Charter preamble.

202. See Relationship Between Disarmament and Development, G.A. Res. 37/84, 37 U.N. GAOR Supp. (No. 51) (98th plen. mtg.) at 69, U.N. Doc. A/37/51 (1982); Economic and Social Consequences of the Armaments Race and Its Extremely Harmful Effects on World Peace and Security, G.A. Res. 3075, 28 U.N. GAOR Supp. (No. 30) (2192d plen. mtg.) at 14, U.N. Doc. A/9030 (1973).

203. Repertory of Disarmament Research, supra note 200, at 75 n.*. Prominent among the recent international inquiries into the connection between arms control and economic growth are the 1982 study by a distinguished group of governmental experts, sponsored by the United Nations under the leadership of Sweden's Inga Thorsson, see Disarmament and Development, supra note 73; a 1984 United Nations study of the possibility of creating a multilateral trust fund to aid economic growth, paid for by savings in military budgets, see International Disarmament Fund, supra note 71; the two important reports of the Brandt Commission, see A Programme for Survival, supra note 2, at 117-25, and Indep. Comm'n on Int'l Dev. Issues, Common Crisis North-South: Cooperation for World Recovery, Report of Brandt Commission 37-38 (1985); and the Palme Commission Report, supra note 47, at 173-74.

204. Disarmament and Development, supra note 73, at 161; accord Final Document, supra note 70 , \ 4, at 373 .

205. See Repertory of Disarmament Research, supra note 200, at 71-74; Disarmament and Development, supra note 73, at 171-76. At the 1987 conference, the Soviet Union proposed that each future arms control accord should be accompanied by a statement of its financial implications, indicating how much money it will save and what percentage of those funds would be dedicated to development assistance. See [1987] 12 U.N. Disarmament Y.B. 353. U.N. Sales No. E.88.IX.2 (1987); see also International Disarmament Fund, supra note 71, at 19-25 (discussing various possibilities for taxing wealthy and heavily armed states to support development efforts). 
momentum during the $1980 \mathrm{~s}^{206}$ The United States refused even to attend the latest major international conference exploring the association between disarmament and development, convened in New York in 1987.207 A major explanation for this consistent lack of support must again be the independent national calculations of self-interest: in the resource-shifting programs advocated by the United Nations, there is little obvious or immediate benefit drawing the wealthy states to participate. ${ }^{208}$ It is only natural for the developed states to resist the international community's efforts to reach uninvited into the seemingly deepest pockets; when the donor states would get nothing in return for providing the additional aid, the appeals for development assistance will be ignored. ${ }^{209}$

Our program, on the other hand, provides a sound incentive for the developed states: what is in it for them is a world-wide commitment to the specific measures of multilateral disarmament that can build a safe and stable environment for international commerce and culture. Instead of earning simply the warm, rosy feeling from doing charitable work, the developed states under our proposal would receive broadly based, meaningful security assurances that cannot be obtained in other

206. See Brauer, Reviving or Revamping the Disarmament-for-Development Thesis?, Bull. Peace Proposals, Sept. 1990, at 307, 308-09.

207. The International Conference on the Relationship between Disarmament and Development was convened by the United Nations August 24-September 11, 1987, culminating several years of preparations. It was attended by I50 states and its final report has become one of the leading documents in the field. The United States declined to attend the conference, stating that disarmament and development were two distinct issues that could not be considered appropriately in terms of an interrelationship. See [1987] 12 U.N. Disarmament Y.B. 342-44, 371, U.N. Sales No. E.88.1X.2 (1987); Deger, supra note 67, at 523.

208. The developing world has long sponsored proposals for a "New International Economic Order," and the United Nations General Assembly has endorsed the concepts of greater sharing of natural resources and greater power for the developing countries. See G.A. Res. 3201 (S-VI), 6 (Spec.) U.N. GAOR Supp. (No. 1) (2229th plen. mtg.) at 3, U.N. Doc. A/9559 (1974); G.A. Res. 3202 (S-VI), 6 (Spec.) U.N. GAOR Supp. (No. 1) (22x9th plen. mtg.) at 5, U.N. Doc. A/9559 (1984); Disarmament and Development, supra note 73, at 32-37; P. Harrison, supra note 70, at 26 . However, meaningful progress toward actual implementation of this new economic order has been completely blocked. See International Disarmament Fund, supra note 71, at 4; Ivanov, Disarmament, Detente and Development: The Dialectics of Interplay, Disarmament, Spring I986, at 36, 45; W.W. Rostow, supra note 75, at 116.

209. In opening the 1987 conference, the Secretary-General acknowledged that it was simplistic to suppose that reduced military expenditures by the developed states would automatically lead to increases in their development aid to other states, but he argued that both disarmament and development should proceed on their own timetables, as rapidly as possible. See [1987] 12 U.N. Disarmament Y.B. 348, U.N. Sales No. E.88.IX.2 (1987). Nevertheless, the major thrust of these and other efforts to date to link arms control and economic growth have been little more than demands for resource-shifting, with no concrete returns to the states that would provide the funds. Cf. Final Document, supra note 70, โ१ 31, 32, at 376 (resources released via disarmament should be devoted to development). 
ways. ${ }^{210}$ Each group of states would give what it can, in exchange for the type of international behavior that it needs the most. Unlike the previous, largely illusory linkage sponsored over the years hy the United Nations, this is a realistic, politically attractive bargain for both sides.

\section{Precedents}

Because the world has no experience-beyond the inadequate model of the NPT ${ }^{211}$ - with an overt linkage between multilateral disarmament and the explicit financial underwriting of third world development, some will be apprehensive about the plunge into uncharted political currents. When examined more carefully, however, there are ample illustrations of the adoption of similar types of strategies in cognate circumstances-using money freely as an instrument of foreign policy-providing some guidance for our program and some precedents for its success.

The leaders of developed nations do not often, in their international addresses, brag about having purchased security by paying other countries or by threatening withdrawals of aid if the recipients become too obstreperous. However, these themes are common in domestic debates about foreign assistance, and have frequently driven the diplomatic calculations of the United States. Wielding money as a club to induce other states to alter their internal or international policies can be a tricky proposition, but it is frequently adopted. In recent years, the United States has, for example, denied trade benefits to Paragnay because of systematic human rights abuses there, ${ }^{212}$ invoked "Super 301 " trade sanctions against Japan because of its failure to adopt policies that would lead to higher levels of American exports, ${ }^{213}$ and suspended aid and other payments to Panama because of acrimony with the Noriega regime. ${ }^{214}$

Sometimes the links between giving foreign aid and obtaining military advantages have been even more explicit. Several international agreements between the United States and other countries have provided that, in exchange for security-related privileges such as the right to operate military bases on another country's soil, the United States government would endeavor to provide additional foreign assistance to

210. But cf. Beilenson, supra note 68 , at 843 (history suggests that foreign aid will not succeed where it is offered with vague intention of purchasing general influence or friendship).

211. See supra text accompanying notes 164-172.

212. See Paraguayan Asks Special Trade Status, Wash. Post, June 16, 1990, at A17, col. 6 .

213. See Auerbach, U.S. Won't Retaliate Against lndia on Trade, Wash. Post, June 14,1990 , at $\mathrm{Cl}$, col. 5 .

214. See Goshko, U.S. Denies Recognition to Panama, Wash. Post, Sept. 2, 1989, at Al, col. 1 . 
the host government. ${ }^{215}$ For example, the 1983 Agreement on Defense and Economic Cooperation between Greece and the United States ${ }^{216}$ provided that the United States would be permitted to maintain valuable military bases on Greek soil and that the United States would, in return, "assist in the modernization and maintenance of Greek defensive capabilities." 217 When that deal was struck, the U.S. executive branch promptly requested Congress to allocate a half a billion dollars in financing for the Greek armed forces "on terms particularly favorable to Greece."218 Subsequently, when that five-year agreement expired, the United States and Greece struggled through seventeen rounds of negotiations before again finding a formula leading to renewal. The new eight-year package calls for, inter alia, $\$ 345$ million in annual aid to Greece, a donation of about $\$ 1$ billion worth of surplus military materiel, and the waiver of some $\$ 50$ million owed to the United States on previous Greek military purchases. ${ }^{219}$

More broadly, the concept of using financial inducements to achieve foreign policy goals has recently been adopted, or attempted, in other sectors as well.220 There have been numerous proposals for "debt for nature" swaps, under which the wealthy states would write off sizeable loans or provide other forms of relief for poverty-stricken states who might otherwise be forced by cost considerations to adopt national industrialization policies that jeopardize the regional or global environment. ${ }^{221}$ For example, India's Rajiv Gandhi, while prime minis-

215. The United States provides extraordinary support for countries hosting an American military presence, such as Greece, the Philippines, Portugal, Spain, and Turkey. While the overall American foreign aid program rose only slowly during the early 1980 s, assistance to these "base rights" countries jumped nearly $60 \%$, reaching $\$ 1.5$ billion in 1987. See Obey \& Lancaster, supra note 81, at 152; Stanfield, supra note 75, at 1224; see also Tyler, U.S. Near Agreement to Base Aircraft, Ships in Singapore, Wash. Post, July 6, 1990, at A26, col. 1 (United States is negotiating basing agreement with Singapore, in case longstanding agreement with Philippines is not extended).

216. Agreement on Defense and Economic Cooperation, Sept. 8, 1983, United States-Greece, T.I.A.S. No. 10,814 .

217. 1d., art. VIII, T.1.A.S. No. 10,814 , at 5 .

The United States maintains four major bases and twenty smaller installations in Greece. See Goshko, U.S., Greece Conclude New 8-Year Bases Pact, Wash. Post, May 31,1990 , at A35, col. 1 .

218. Letter to Yiannis P. Capsis, Under-Secretary of State for Foreign Affairs of Greece, from Alan D. Berlind, Chargé d'Affaires ad interim, U.S. Embassy, Greece (Sept. 8, 1983) (on file with Columbia Law Review). A year later, Congress granted Greece $\$ 500$ million in military aid. See Pear, Panel Deadlocks on Spending Bill, N.Y. Times, Oct. 6, 1984, at A1, col. 5, A5, col. 1; Tolchin, Conferees Agree on Spending Bill, Ending Deadlock, N.Y. Times, Oct. 11, 1984, at Al, col. 6.

219. See U.S., Greece Sign Agreement on Military Bases, Wash. Post, July 9, 1990, at A16, col. 1; Goshko, supra note 217, at A35, col. 1 .

220. Most obviously, the United States has been quick to extend significant financial support to the new leaders in Panama and Nicaragna, with the Bush Administration moving to provide up to $\$ 800$ million in new aid to states that evicted regimes that the United States had opposed. See J. Baker, supra note 11, at 2.

221. See Gardner, supra note 1, at 33 ("India may phase out the use of 
ter, called for creation of an $\$ 18$ billion international environment fund to develop and promote technologies that could facilitate exploitation of natural resources without environmental degradation. ${ }^{222}$ Similarly, the Bush Administration recently reversed course and endorsed an emerging treaty that would create a $\$ 100$ to $\$ 250$ million trust fund to assist developing countries in adopting substitute technologies to permit less reliance upon ozone-depleting chlorofluorocarbons in refrigeration and other functions. ${ }^{223}$

chlorofluorocarbons, China may moderate its burning of coal, Brazil may stop the destruction of its Amazon rainforest, but only at a price. That price will be new forms of multilateral assistance."); Gibson \& Curtis, A Debt-for-Nature Blueprint, 28 Colum. J. Transnat'l L. 331, 335-53 (1990).

222. See Worsnip, Gandhi Proposes Environment Fund at Non-Aligned Summit, Reuter Library Report, Sept. 5, 1989 (LEXIS, Nexis library, CURRNT file). Gandhi's Planet Protection Fund would come under United Nations auspices and would support research into environmentally sound technologies, to be supplied free of charge to member states. See id.; see also Planet-Protection Costs, Boston Globe, Sept. 8, 1989, at I4, col. I (editorial endorsing concept, but noting that it will probably not succeed in attracting political support or substantial funding).

223. See Morning Edition (Nat'l Public Radio broadcast, May 11, 1990) (transcript on file with Columbia Law Review); Frankel, Governments Agree on Ozone Fund, Wash. Post, June 30, 1990, at Al, col. 6; Weisskopf, U.S. Drops Opposition To CFC Phaseout Fund, Wash. Post, June I6, I990, at A1, col. 5. In the I987 Montreal Protocol, 54 countries have agreed to reduce by half their production of chlorofluorocarbons (CFCs), used in refrigerators, aerosol sprays, and other consumer products, because these chemicals were recognized as dangerous to the global atmosphere. See Montreal Protocol on Substances that Deplete the Ozone Layer, Sept. 16, I987, 26 I.L.M. I550 (entered into force Jan. 1, 1989). More recently, the harm to the ozone layer has been revealed to be even greater than previously thought, and efforts have accelerated to induce additional countries to sign the Montreal Protocol (especially the developing countries, where production of CFCs is expected to increase sharply) and to enhance that treaty by cutting back still further on the use of the hazardous chemicals. The United States initially played a leading role in the negotiations, and helped design the plan for funding developing states who would agree to convert to use of environmentally sound, but more expensive, alternatives to CFCs. In May 1990, however, the Bush Administration reversed course on the trust fund, leading an Indian spokesperson to comment that India and other similar countries were then unlikely to join the Protocol, and a Norwegian environment official to suggest that under those circumstances it would be difficult to persuade developing states to make the financial sacrifices necessary to promote environmental quality.

However, the United States partially changed policy again, in June 1990, under intense international and domestic political pressure, avoiding becoming the only nation to oppose creating a trust fund of some sort. White House Chief of Staff John $\mathrm{H}$. Sununu, who had resisted the proposal on the grounds of cost and the precedent it might establish in support of other types of aid to developing states, announced that the United States would now support the assistance program because it met the "essential criteria" of having adequate scientific evidence of the harms caused by CFCs, strong evidence that the fund would successfully address the problem, and a reasonable and predictable level of expenditures needed. See Weisskopf, supra, at Al, col. 5; Weisskopf, Conferees Agree on Ozone Plan, Wash. Post, Aug. 4, I990, at A4, col. I; Cahan, Fixing the Hole Where the Rays Come In, Bus. Week, July 2, 1990, at 58, 58. Our proposal for similarly linking disarmament and development could pass those same types of tests. 
In other instances, too, the United States and other developed countries have agreed to pay substantial sums of money to the developing states to help induce them to adopt policies and programs that serve mutual interests. Whether the poorer states would have followed the enlightened course anyway, or whether they could have afforded anything more than a short-sighted perspective, is unclear in each instance, but the logrolling has been successful. In the World Health Organization, for example, the United States has provided assistance to developing states to encourage the implementation of public health programs that combat disease and epidemics; the most immediate beneficiaries are the local populations, but all states are advantaged when mass illness is reduced.224 Similarly, through the International Civil Aviation Organization, the United States has provided funds to aid other states in the construction and enforcement of antihijacking and antiterrorism equipment and training, again supporting a set of measures that redounds to the benefit of both the recipient and donor. ${ }^{225}$

The most dramatic current illustration of using money as a grease for easing international relations may be the 1990 arrangements through which Western countries will be providing billions of dollars in loans and credits to the Soviet Union in exchange for the U.S.S.R.'s withdrawing its objections to NATO membership for the reunited Germany-in Jim Hoagland's terms, "a bribe worth giving."226 The allies authorized each state to pursue its own course regarding assistance to Moscow, and although the United States seems unlikely to offer anything beyond technical advice in the near term, other states have hurried to do more. ${ }^{227}$ West Germany, in particular, has pledged up to $\$ 8$ billion in aid to the U.S.S.R., prompting President Gorbachev to reorient Soviet policy and acquiesce in the enlargement of the Western alliance. ${ }^{228}$

The United States has shown no compunctions about marshalling monetary assets to advance its Middle East policy, as evidenced by President Bush's recent public offer of financial assistance to Jordan's King Hussein, to attempt to enlist his support for United Nations economic sanctions against Iraq. ${ }^{229}$ Shortly thereafter, the United States unilat-

224. See UNESCO Youth Institute, Toward Mankind's Better Health 27-32 (1963). 225. See Ott, ICAO Upgrades Security Unit as Part of Antiterrorist Effort, Aviation Week \& Space Tech., May 1, 1989, at 109.

226. Hoagland, Uniting Germany: A Little 'Bribery', Wash. Post, July 3, 1990, at A23, col. 1 .

227. See Suro, Summit 1s Divided on Aid to Moscow, N.Y. Times, July 11, 1990, at A1, col. 5; Hoffman, Bush Holds Off on Economic Aid to Soviets, Wash. Post, June 30, 1990, at A23, col. 3; Moore, Cheney Would Tie Aid to Soviet Military Cuts, Wash. Post, June 26, 1990, at A17, col. 1 .

228. See Fisher, Bonn to Pay $\$ 8$ Billion for Soviet Troops in E. Germany, Wash. Post, Sept. 11, 1990, at A14, col. 1; Lee, Gorbachev Drops Objection to United Germany in NATO, Wash. Post, July 17, 1990, at Al, col. 4.

229. See Tyler, Bush Offers Aid to Jordan If Iraq Embargo Honored, Wash. Post, 
erally forgave Egypt's $\$ 7$ billion debt, as an expression of appreciation for the leading role that President Mubarak played in rallying Arab support for the American resistance to the invasion of Kuwait.230 And the United States has also used the withdrawal of financial assistance as a policy tool for punishing states that pursue policies contrary to American objectives: when Yemen voted against the United States-sponsored United Nations Security Council resolution to authorize the use of force against Iraq in December 1990, "a senior American diplomat was instructed to tell [a Yemeni diplomat] 'That was the most expensive no vote you ever cast'-meaning that it would result in an end to America's more than $\$ 70$ million in foreign aid to Yemen."231 Other forms of economic assistance tied to foreign states' domestic political decisions in other contexts, including incentive deals solely between the developed states, ${ }^{232}$ have also been implemented. ${ }^{233}$

It requires only a short conceptual leap to move from providing economic assistance in exchange for basing rights, trade policies, or environmental protection to providing similar assistance in exchange for arms limitation. The dangers of the spread of technologically so-

Aug. 15, 1990, at Al, col. 4. Jordan is heavily dependent upon trade with Iraq, and any decision to conform to the Security Council's mandatory embargo on Iraq would strain the fragile Jordanian economy. At the same time, Jordanian nonparticipation would rob the sanctions package of much of its impact, easing the pressure upon Iraq. The United States quickly offered to insert money into Jordan's calculations, proposing to provide direct financial support if Jordan would support the United Nations policy. See id.

230. See Friedman, Baker Foresees a Long Stay for U.S. Troops in Mideast; Urges a Regional Alliance: Egypt Debt Erased, N.Y. Times, Sept. 5, 1990, at Al, col. 6. The United States also facilitated India's receipt of loans from the International Monetary Fund in return for Prime Minister Chandra Shekhar modifying India's foreign policy and permitting American transport planes to refuel in India en route to the Desert Storm fighting. See Coll, Policy on U.S. Planes Threatens India's Leader, Wash. Post, Feb. 17, 1991, at A32, col. 2.

231. Friedman, How U.S. Won Support to Use Mideast Forces, N.Y. Times, Dec. 2, $1990, \S 1$, at 1 , col. 5 .

232. Recently the United States announced that it would give $\$ 1$ million each to Canada and Switzerland for their assistance in obtaining the guilty plea of a Panamanian bank in the largest money-laundering prosecution in American history. The reward was described as part of a new program to elicit greater international cooperation in tracing the flows of drug money, providing an incentive for states to relax their traditional secrecy regarding banking transactions that could be used to shield illegal proceeds. See Isikoff, U.S. to Pay Nations for Aid in Drug Case, Wash. Post, Aug. 15, 1989, at A14, col. 1.

233. Other countries have also demonstrated a propensity to utilize economic power to pursue political ends. For example, the 1973 oil embargo was an attempt by several Arab states to influence other nations' policies toward Israel. See Comment, supra note 191, at 983-84. More recently, there have been reports that Israel was preparing an arms sale to Argentina, on terms favorable to the purchasers, in exchange for Argentina's breaking off its program of cooperation with Egypt in the development of ballistic missiles. See British Broadcasting Corporation, Summary of World Broadcasts, Argentina Newspaper Says Condor Project with Egypt Cancelled for Sake of Israeli Deal, Apr. 6, 1989 (LEXIS, Nexis library, CURRNT file). 
phisticated weapons are not too dissimilar from the dangers of the spread of terrorism or illicit drugs. In each instance, the wealthy states can pay the poorer states to support enforcement programs that will benefit everyone. The concept of negotiating an economic quid pro quo to promote United States national security is therefore hardly revolutionary. The strategy of adapting that process-in direct, overt mechanisms-to serve the achievement of multilateral disarmament should not now be too shocking.

The success and pervasiveness of these partial precedents could support an argument even broader than the one we make: one could assert that the principle of linking disarmament measures with development assistance ought to be applied not only in future arms control agreements, but immediately, through existing programs of bilateral foreign aid and through contemporary multilateral assistance administered by the World Bank, ${ }^{234}$ the International Monetary Fund (IMF), ${ }^{285}$ the Organization for Economic Cooperation and Development, ${ }^{236}$ and others. Because these institutions already carry such substantial weight in international economic relations, it might be advantageous to enlist them, too, to support if not to implement our program.

Certainly, the aid program we propose must be fully coordinated with the existing bilateral and multilateral development enterprises already in place. ${ }^{237}$ Judicious application of all available international financial tools will help avoid waste and attain the maximum political impact. But the existing programs are simply insufficient to deal with the immense challenges of fostering economic development, even before the concerns of disarmament are factored in. Current cooperative development efforts are certainly substantial-the World Bank target for the current fiscal year is $\$ 16$ to $\$ 18$ billion in regular bank loans and another $\$ 5.7$ billion in subsidized lending 238 - but they have, by the Bank's own calculations, fallen dangerously far behind the increasing levels of need. In fact, new loans to the developing world fell in

234. See Bureau of Public Affairs, U.S. Dep't of State, Gist: The World Bank 1 (Mar. 1989) ("The World Bank is the preeminent source of long-term official finance and policy advice for developing countries.") (on file with Columbia Law Review).

235. See Bureau of Public Affairs U.S. Dep't of State, Gist: International Monetary Fund 1-2 (May 1989) (International Monetary Fund supports members' efforts to maintain orderly currency exchange rates and to harmonize trade policies and generates the equivalent of approximately $\$ 4$ billion in loans per year to developing countries) (on file with Columbia Law Review).

236. See Bureau of Public Affairs, U.S. Dep't of State, Gist: Organization for Economic Cooperation and Development (OECD) 1-2 (Dec. 1989) (OECD's 24 members, including United States, Canada, and most of Western Europe, collaborate on wide range of issues, including provision of economic assistance to developing countries) (on file with Columbia Law Review).

237. See Pipart \& Sada, supra note 76, at 155 (discussing need to coordinate all programs of economic assistance from diverse donor states and institutions).

238. See Rowen, Soviet Group to Meet IMF, World Bank, Wash. Post, Sept. 17, 1990, at A17, col. 1, A18, col. 4. 
1989 to their lowest level in ten years, and the mountain of existing debt imposes additional hardships upon many in the poor states. ${ }^{239}$

With this acknowledged level of need, it is unlikely that the bulk of our linkage proposal could be accomplished through existing mechanisms, either bilateral or multilateral. First, regarding current national aid programs, most states would not reliably pledge to govern their future assistance programs in this way. The countries that now make bilateral help available do so for a variety of particularistic reasons, including humanitarian concerns and foreign policy advantages (including disclosed and undisclosed agreements of the kinds described above $\left.{ }^{240}\right)$. The aid is provided episodically, depending heavily upon transitory perceptions of national interest, ${ }^{241}$ and states have been reluctant to band together in providing sustained joint assistance, or even to promise to continue the flow of unilateral aid. While some countries, therefore, might elect to institute on their own a linkage program such as the one we recommend, there is little reason to hope that many would do so with consistency or with the volume of assistance that we project would be necessary to tackle the problem.

Second, concerning existing multilateral lending institutions, there are again serious questions whether their considerable financial muscle could, or should, be enlisted in direct support of our proposal. To begin with, the World Bank and other organizations already impose numerous economic conditions upon their lending, designed to make it likely that the loaned funds will be used productively for economic development and that the loans will be repaid. ${ }^{242}$ Any new disbursement requirements (such as those related to arms control) could not simply supplant these original conditions, lest countries meeting the disarmament requirements become free to squander the funds received. 1nstead, the new tests would have to be imposed in addition to the existing ones. The resulting combination of hurdles might then be more than many countries would choose or be able to meet. Even from the perspective of the lender, it might be better strategy to continue to concentrate the institutions' efforts in the economic field-the subject

239. See id.

240. See supra text accompanying notes 211-219.

241. The United States includes a wide variety of political considerations-going well beyond the security concerns related to arms control-in national decisions regarding grants of foreign aid. For example, for a decade the United States continued to provide military assistance to Pakistan, despite the fact that Pakistan was seeking to develop a nuclear weapons capability, because Pakistan was also providing indispensable support to the American effort to arm the rebels resisting Soviet domination of Afghanistan. See L. Spector, supra note 29, at 125. Similarly, the United States helped Iraq, despite Iraqi development and use of poison gas in war and against its own people, in order to prevent the ascendancy of Iran. See Ajami, The Summer of Arab Discomfort, Foreign Aff., Winter 1990-91, at 1, 19.

242. See Nelson, The Diplomacy of Policy-Based Lending, in Between Two Worlds: The World Bank's Next Decade 67, 71-72 (R. Feinberg ed. 1986). 
that they know the best-rather than to stretch to acquire new expertise and fulfill new mandates.

More importantly, the imposition of what would surely be seen as "political" rather than strictly economic conditions on lending by existing multilateral institutions would undoubtedly strike many recipient nations as a new form of unwarranted imperialism. That is, the raw use of the wealthy nations' economic hegemony to impose still further domination on the recipients through novel World Bank intervention in national security issues is fundamentally different from a consensual tradeoff for which both sides would freely bargain in the arms control treaty-making process. Over the past decades, countries have come to expect that the World Bank's only conditions on lending will be based upon economic rationales and not, for example, upon determinations whether the recipient was sustaining a democratic form of government, respecting human rights, or deploying armies threatening to its neighbors. Newly created financial institutions (including those to be founded under the treaties we envision) may plausibly include new conditions in their own charters or policies, ${ }^{243}$ but as Alexander Shakow points out, "from the very beginning, the nations founding the World Bank and the International Monetary Fund agreed that lending by these institutions should be free from political considerations." 244 The developing countries would surely resent any belated efforts to change the long-standing rules and impose new political demands. ${ }^{245}$

The World Bank's uneven record of attention to one major issue reaching beyond sheer economics is instructive, too. In 1987, Bank President Barber Conable had committed the institution to sweeping environmental reforms, pledging that ecological concerns would assume far greater prominence in the organization's plans and in its

243. For example, the new European Bank for Reconstruction and Development requires that loan recipients be market-oriented democracies and respect basic human rights. See I. Shihata, The European Bank for Reconstruction and Development: A Comparative Analysis of the Constituent Agreement, app. 1, at I11 (1991).

244. Telephone interview of Alexander Sbakow, World Bank Director of External Affairs (Dec. 28, 1990). It might also prove impossible, as a political matter, to amend the World Bank's Articles of Agreement to modify the longstanding loan policies. The United States and other developed countries provide the bulk of Bank funds, but under the organization's weighted voting system, they do not control the decision-making process. Amendments to the Articles require acceptance by an $85 \%$ majority of the total voting power, which implies a very broad agreement among the members on the desirability of an amendment. Id.

245. Under one set of circumstances, it might be appropriate for the World Bank, IMF, and other existing multilateral lenders to require adherence to and compliance with arms control agreements as a condition for future lending. That is, if a new agreement had such strong international support that it were nearly universal (for example, if only a handful of countries refused to sign it), the treaty might be said to embody a new, no longer controversial, international legal norm. Under those circumstances, multilateral lenders might seriously consider, as a matter of policy, not extending credit to the few holdouts or to any countries that renounce or violate their treaty obligations, and there might be worldwide support for such action. 
processes for evaluating, approving, and overseeing development projects. In implementing that goal, the World Bank has hired some sixty new environmental experts, and some noteworthy advances have been achieved. Yet at least some critics complain that the overall performance has lagged seriously behind the promises, arguing that environmental concerns are still a much lower priority than immediate economic feasibility. ${ }^{246}$ Something like our linkage proposal can be instituted, therefore, not by simply grafting its principles onto existing programs, but only by eliciting new international mechanisms and legal relationships.

\section{Alternatives}

Despite these partial precedents, the program we suggest will be a novel departure from most previous strategies for pursuing national security. We would not sponsor it if there were less burdensome alternatives that had a plausible probability of success, but unfortunately, existing international law has provided few other attractive models for dealing with these modern challenges.

We have already discussed the inadequacies of the current configuration of incentives for entering arms control accords and the paucity of legal responses available in cases of breach. ${ }^{247}$ One other strategy deserves comment: the effort to retard the further dissemination of dangerous military technology solely through "supply side" restrictions on the export of goods and technology.248 Regarding nuclear, ${ }^{249}$ chemical, ${ }^{250}$ and other weaponry, ${ }^{251}$ the advanced states have created

246. See Rich, The Emperor's New Clothes: The World Bank and Environmental Reform, 7 World Pol'y J. 305, 316-25 (1990); World Comm'n on Env't and Dev., Our Common Future 336-39 (1987).

247. See supra notes $105-136$ and accompanying text.

248. See D. Fischer, supra note 65 , at $49-56$.

249. In 1977, a group of supplier states formed the so-called "London Club," which established a list of nuclear materials, equipment and technology that ought to be confined by international safeguards prior to export. Another group with a similar mission, the "Zangger Committee," also helps define the nuclear-related items that can be freely exported to all states, as well as those that require controls. See Goldblat, supra note 21 , at 374 .

250. Since 1985, the "Australia group," composed of 15 industrialized countries, has met informally to coordinate national policies regarding the export of chemicals and equipment that might have weapons applications. By developing a uniform "trigger list" of controlled items, the group hopes to promote flexible, sustainable collaboration, avoiding the economic pressures that arise when any one state imposes export controls that are tighter than those of its economic rivals. See Ember, supra note 25, at 11 .

251. The United States and 16 other countries are-members of the Coordinating Committee for Multilateral Export Controls (COCOM), charged with aligning members' policies regarding the shipment of strategic goods and technology to the Soviet Union and other states. COCOM maintains a control list of embargoed items and evaluates individual proposed exports that might have weapons applications. See Bureau of Public Affairs, U.S. Dep't of State, Gist: US Exports: Strategic Technology Controls 1-2 (May 1989). Recently, however, the COCOM control list has been modified in impor- 
suppliers' cartels, attempting to preclude easy access to destabilizing arms or the components thereof. ${ }^{252}$ These measures have attained a significant level of success, ${ }^{253}$ but as with all oligopolies, there have been leaks. ${ }^{254}$ In addition, overly restrictive export controls exact a price on the developed countries as well, impeding commerce and retarding the inventiveness and cross-fertilization that accompany the free market in goods. ${ }^{255}$ More critically, the imposition of export controls, even when they are designed in an even-handed form and applied without invidious discrimination, evokes profound resentment from the developing states, who see the tactic as a lingering tool of hegemony wielded by wealthy economic imperialists. ${ }^{256}$

The problem of weapons proliferation, moreover, is not simply on the supply side; the developing states' demand for the destabilizing forces must also be curbed.257 Even a tight regime of export controls may do little to impinge upon the development of a truly indigenous

tant ways, increasing the ability of Warsaw Pact and third world states to gain access to weapons-related technology. See Milhollin, supra note 34, at C2, col. 1 .

252. In April 1987, seven developed Western states (the United States, Canada, the United Kingdom, France, West Germany, Italy, and Japan) formed the Missile Technology Control Regime, an agreement to enact parallel domestic restrictions in each state to regulate the export of nuclear-capable missile systems, production technologies, and key components. These criteria apply to any missile capable of carrying a 500-kilogram payload over 300 kilometers. To date, the Soviet Union and China, two important potential suppliers of missiles for developing states, have not formally joined the control regime, although the U.S.S.R. has indicated that it will largely conform its own practices to the international standards. See Jones \& Müller, supra note 15, at 19; Morrison, supra note 36, at 971; Nolan, supra note 36, at 12; Schrag, supra note 36, at 14 .

253. See Donovan, Iraqi Smuggling Effort Bombs, Arms Control Today, Apr. 1990, at $27,27$.

254. A conspicuous example of the failure of the international system of controls on the proliferation of weapons-related technology and goods is provided by the construction of the chemical weapons facility at Rabta, Libya. The United States government has alleged that the plant was made possible by covert, illegal shipments from commercial facilities in West Germany and other countries, evading a multilateral network of restrictions over a period of years. See Bunn, U.S. Charges Libyan Plant Desigued to Produce Chemical Weapons, Arms Control Today, Jan./Feb. 1989, at 26, 26-27.

One reason for the difficulty in sustaining leak-proof controls on the export of chemical, nuclear, or other weapons-related materials is the fact that, at least in market economies, the government's program of supply restrictions usually requires the active collaboration of, and substantial self-policing by, private entities because the government does not have the resources to monitor each export shipment. These private firms, however, are motivated largely by profit-seeking opportunities, and have often participated eagerly in black-market exports. See D. Fischer, supra note 65, at 20.

255. See Quester, The Non-Aligned States and Arms Control, in Arms Control: The Multilateral Alternative, supra note 18, at 113, 132.

256. See D. Fischer, supra note 65 , at 10; Mayorsky, supra note 54, at 89 ; Mohan \& Subrahmanyam, supra note 46 , at 233.

257. Cf. V. Utgoff, supra note 65 , at 8-9 (proposing methods to reduce demand for chemical weaponry, via promises of timely, effective assistance to victims of chemical weapons). 
production capability inside a determined state. The international community has considered a variety of mechanisms through which the leading military powers could enhance the security of developing countries, and hence reduce their reliance upon nuclear or other advanced weaponry. ${ }^{258}$ Multilateral disarmament, with economic development as a sweetener, can provide the needed element of incentives to make the overall approach work. We certainly do not propose that the developed states abandon their other efforts at nonproliferation; all available policy tools ought to be applied as consistently and as deftly as possible. What we advocate is enriching the range of tactics available to deal with modern threats: the developed states should also proffer some carrots, rather than being dependent solely upon increasingly ineffective sticks. ${ }^{259}$

\section{Conclusion}

There are plenty of reasons why this program may not work. Some of the states that have been among the most problematic hold-outs against prior arms control efforts may similarly resist-and even be offended by-this proposed bargain. In some instances, the leaders of developing countries may be so corrupt and self-interested that they care little about local economic well-being and the fate of their own people; such leaders will continue to pursue their own courses, clinging to power and making trouble internationally, with the offer of development assistance holding no allure. ${ }^{260}$ And some states may be so impoverished, poorly organized, and mismanaged that no reasonable amount of foreign assistance will be able to make a substantial dent until internal decisions are implemented to reconfigure the national economic and political structures. 261

On the other hand, the proposal just might work. It provides a mutually beneficial international tradeoff, and nothing succeeds like an appeal to self-interest. If the international community can collaborate to reorganize the structure of states' incentives and costs that currently

258. Among the strategies under discussion have been: networks of treaties or alliances; declarations of "no first use" of specified weapons; commitments ("positive security assurances") to come to the aid of countries victimized by nuclear aggression; and commitments ("negative security assurances") not to use nuclear weapons against nonnuclear-weapons states. See [1988] 13 U.N. Disarmament Y.B. 223-33, U.N. Sales No. E.89.IX.5 (1988).

259. Cf. L. Reynolds, supra note 2, at 128 (noting self-interest of developed states in aiding others toward economic growth); Note, supra note 109, at 26 (comparing use of positive inducements, such as supply guarantees, and of negative sanctions, such as trade embargoes, as tools of nonproliferation policy).

260. See P. Harrison, supra note 70 , at 292; L. Reynolds, supra note 2, at 104; Beilenson, supra note 68 , at 842 .

261. See J. Baker, supra note 73, at 1 ; George Shultz, Efforts for Peace in Africa, Address, reprinted in 88 Dep't St. Bull. No. 2141, Dec. 1988, at 20, 22; Thee, supra note 103 , at 53. 
prevails, if we can provide positive inducements to tempt developed and developing states together to pursue these unconventional, but strongly reinforcing leads, then there is a chance that the scheme will meet its objectives. Tying together the diverse needs of very different groups of states, the international community may be able to resolve a nest of problems with a single, straightforward approach.

Nations today have every incentive to explore new approaches to international peacekeeping, including even radical departures from the failed policies of the past generations. No one surveying the global panorama today can be content about the human condition or sanguine about the ability to avoid bloody conflict. The developing states are a miasma of poverty, despair, and helplessness-a perfect breeding ground for international trouble. The developed states are leaning on a precarious prosperity, as the threat of swiftly delivered, highly accurate, and extremely destructive weaponry spreads around the world.

The idea of giving away money will not initially be a popular one, ${ }^{262}$ but careful thought will lead states to recognize that the danger of proliferation is profound. The developed states are losing control of their own security, and they will require the active cooperation of the developing world to build a more stable environment. A realistic appraisal of the emerging threats is required, along with a willingness to deal with the modern world as it is-or as it is becoming, in the postCold War era of multilateralism.

An important conceptual leap is therefore required: for a generation, security leaders have taught us to think that the principal functions of national defense expenditures are to deter bilateral nuclear war, to encircle a relentlessly hostile opposing superpower, and to gird ourselves against a single, Manichaean assault. We need now to shift to a more complicated, sophisticated understanding that the dangers of the modern world come in all sorts of forms and from diverse locations. The enterprise remains the same-promoting international stability and national security-but now we are compelled to adopt very different strategies and policies to support it. ${ }^{263}$

A colossal bargain-or series of bargains-can therefore be struck. The developed states have relative wealth, and they have always been willing to spend their treasure to pursue national security; here is a new, cheaper, safer way to achieve that goal. The developing states

262. See P.T. Bauer, supra note 72, at 42-43; Beilenson, supra note 68 , at $841-43$. 263. Cf. W.W. Rostow, supra note 75, at 75-76:

Faced with this fact [the diffusion of power], there are three choices open to the Soviet Union and the United States. We can stumble into a war and destroy a large part of what man has built on the face of the earth and a large part of the world's population. We can continue the cold war until the diffusion of power removes the capacity to decide from Moscow and Washington. Or, working constructively together, we can [strongly influence] the terms on which power will become diffused. 
desperately seek financial assistance in the struggle to modernize; here is a different path to obtain substantial quantities of assistance by eschewing the chimerical pursuit of advanced arms.

The world currently faces immense, intractable problems: the unmet needs for development assistance, the emerging risks associated with the proliferation of sophisticated weaponry, and the traditional inability of the system of international law to cope with those stresses. We should now be able to fashion a single, symbiotic solution. 